\title{
ZAŠTITA JAVNOGA INTERESA U RASPOLAGANJU JAVNIM DOBROM U OPĆOJ UPORABI
}

Dr. sc. Aleksandra Popovski, poslijedoktorandica

Pravni fakultet Sveučilišta u Rijeci

\author{
UDK: 35.073 \\ Ur.: 9. siječnja 2017. \\ Pr.: 16. siječnja 2017. \\ Izvorni znanstveni rad
}

\begin{abstract}
Sažetak
Interes kojega društvena zajednica ima po pitanju korištenja javnoga dobra u općoj uporabi pravno je priznat kao javni interes. Radi zaštite javnoga interesa, osoba javnoga prava nije ovlaštena javno dobro otuđiti, niti ga opteretiti stvarnopravnim osiguranjem tražbine. Mogućnost raspolaganja javnim dobrom svedena je na davanje odobrenja za vremenski ograničeno $i$ opozivo korištenje toga dobra koje nadilazi opću uporabu. Odobrenje se može dati u formi upravnoga akta, koncesije ili ugovora. Upravni akt i koncesija omogućuju primjenu raznih pravnih sredstava kojima osoba javnoga prava može utjecati na sadržaj upravnopravnog odnosa $i$ zaštititi javni interes $u$ slučaju njegove ugroze. S druge strane, ugovor kao pravni osnov korištenja javnoga dobra ne omogućuje osobi javnoga prava autoritativno postupanje $i$ trenutnu zaštitu javnog interesa. Unatoč tomu, u hrvatskom su zakonodavstvu upravni akt i koncesija podzastupljeni, dok je ugovorima dan znatan prostor. Predmet rada stoga je analiza režima raspolaganja javnim dobrom u općoj uporabi radi kritičkog preispitivanja primjerenosti hrvatskih pozitivnih propisa $s$ gledišta zaštite javnoga interesa te predlaganja normativnih intervencija $u$ cilju unaprjeđenja postojećega pravnog okvira.
\end{abstract}

Ključne riječi: javno dobro, vlasništvo, raspolaganje, opća uporaba, posebna uporaba, upravni akt, koncesija, ugovor.

\section{UVOD}

Status javnoga dobra u općoj uporabi dodjeljuje se različitim dijelovima materijalnog svijeta koji kao cjelina služe ispunjavanju konkretnih potreba zajednice. Glavna odrednica pravnog režima toga dobra pravo je svih pripadnika društvene zajednice da ga koriste sukladno njegovoj namjeni. Neovisno o tomu izražava li se opća uporaba kao korištenje vode koja se putem vodoopskrbnog sustava izdvaja iz javnoga vodnog dobra za piće, kao prometovanje motornim vozilom po cesti ili kao nešto treće, ona u svojoj biti predstavlja zadovoljenje specifičnih potreba ključnih za život svakog čovjeka. Interes kojega društvena zajednica ima po pitanju korištenja javnoga dobra zbog toga je pravom priznat i zaštićen kao javni interes. Štoviše, javni 
interes osnovni je razlog zbog kojega je namjena nekog dobra određena kao javna, a uporaba kao opća.

Kako bi se javnome interesu pružila odgovarajuća zaštita, javno dobro podvrgnuto je jedinstvenom javnopravnom režimu kojeg karakteriziraju pripadnost osobama javnog prava te snažna ograničenja vlasničkih ovlasti, posebice ovlasti raspolaganja. Temeljni liberalističko-individualistički karakter privatnoga vlasništva u određenim situacijama, naime, predstavlja prepreku učinkovitoj zaštiti javnoga interesa vezanoga uz javno dobro. Bitna pitanja vlasničkopravnog statusa i pravnog režima javnoga dobra u općoj uporabi stoga se uređuju normama javnog, a ne privatnog prava. Specifičnost javnog prava autoritativno je postupanje javne vlasti kada je potrebno zaštititi javni interes, pa su javnopravne norme pogodno sredstvo za takvu regulaciju. Iako danas nailazimo na širok spektar pristupa problematici zaštite javnoga interesa, te se regulacija pravnog režima javnog dobra razlikuje od države do države, vidljiva su neka zajednička obilježja i tendencije koje omogućuju razlikovanje dvaju osnovnih modela. Na najopćenitijoj razini tako možemo izdvojiti francuski model javnoga vlasništva i njemački model modificiranoga privatnog vlasništva. Temeljno obilježje oba modela visoka je razina zaštite javnoga interesa u pravnom režimu javnog dobra u općoj uporabi. Razlike među modelima javljaju se s obzirom na mehanizme zaštite javnoga interesa. Tako je u Francuskoj javno dobro u općoj uporabi izuzeto od primjene normi privatnoga prava i podvrgnuto javnome vlasništvu. Zaštita javnoga interesa temelji se na očuvanju javne namjene javnoga dobra. Nužnost očuvanja javne namjene za posljedicu ima tri važna obilježja koja dominiraju pravnim režimom toga dobra. Riječ je o zabrani otuđenja, zabrani provedbe prisilnog izvršenja i zabrani stjecanja vlasništva dosjelošću. Povrh toga, mogućnost raspolaganja javnim dobrom u cijelosti je ograničena na nekolicinu javnopravnih instituta te se općenito smatra kako privatnopravna raspolaganja nisu u skladu s javnom namjenom javnoga dobra. ${ }^{1} \mathrm{~S}$ druge strane, u Njemačkoj je javno dobro u općoj uporabi načelno objekt privatnog vlasništva. No, pravni režim javnoga dobra ima dvojni karakter te je uređen kako normama privatnog prava, tako i normama javnog prava. Pritom valja imati u vidu da se norme privatnog prava primjenjuju iznimno, samo ako njihova provedba ne ugrožava javni interes. Posljedično tomu, iako u njemačkom pravu nije izričito propisana zabrana otuđenja javnoga dobra u općoj uporabi, pravni status toga dobra gotovo je jednak statusu dobara izvan pravnoga prometa. Radi zaštite javnoga interesa, privatnopravna raspolaganja javnim dobrom koja bi utjecala na javnu namjenu toga dobra nisu dopuštena. ${ }^{2}$

Hrvatski zakonodavac je režim javnoga dobra u općoj uporabi zasnovao na njemačkom modelu te ga nastojao urediti u skladu s individualističko-liberalističkim konceptom privatnog vlasništva. Posljedično tomu, javno dobro nalazi se u privatnom

1 Vidi Auby, Jean-Marie, Bonn, Pierre, Droit administratif des biens, 3. izd., Paris, Dalloz, 1995., str. 66. do 68., 94. do 98. i 161. do 162. te Gillet-Lorenzi, Emmanuelle, Traoré, Seydou, Droit administratif des biens, Paris, Centre National de la Fonction Publique Territoriale, 2007., str. 64. do 70.

2 Vidi Wolff, Hans J., Bachof, Otto, Stober, Rolf, Verwaltungsrecht, Band 2, München, Verlag C. H. Beck, 2000., str. 698. do 699. i Papier, Hans Jürgen, Recht der Öffentlichen Sachen, Berlin, Walter de Gruyter, 1977., str. 24. do 27. i 82. do 86. 
vlasništvu osoba javnoga prava. Zakonom o vlasništvu i drugim stvarnim pravima određeno je kako osoba javnoga prava kao vlasnik u pravnim odnosima ima jednak položaj kao i privatni vlasnik, ako zakonom nije što drugo određeno. ${ }^{3}$ Ovlast osobe javnoga prava da zaštiti javni interes pri raspolaganju javnim dobrom u općoj uporabi djelujući iure imperii stoga ovisi o zakonima kojima je uređen pravni režim javnoga vodnog dobra, cesta i željezničke infrastrukture kao triju kategorija javnoga dobra u općoj uporabi koje postoje u našem pravnom sustavu te, supsidijarno, o zakonima kojima je uređen pravni režim imovine osoba javnoga prava. Relevantni zakoni, međutim, mehanizme zaštite javnoga interesa u režimu raspolaganja javnim dobrom u općoj uporabi ne uređuju ni sustavno, niti dosljedno. Osim toga, raspolaganje javnim dobrom regulirano je malim brojem odredaba razasutim u različitim zakonskim i podzakonskim aktima. Jedna od najvažnijih posljedica podnormiranosti ovoga pravnog područja nedostatak je ovlasti koje bi osobi javnoga prava omogućile učinkovitu zaštitu interesa društvene zajednice u pogledu javnoga dobra. Zakonima koji uređuju pravni režim javnoga vodnog dobra, cesta i željezničke infrastrukture tako je dopuštena široka primjena različitih privatnopravnih instituta u raspolaganju javnim dobrom u općoj uporabi. To samo po sebi ne bi predstavljalo problem, kada bi uz takve institute privatnog prava bili propisani i javnopravni mehanizmi zaštite javnog interesa u slučaju njegove ugroze. Takvi sigurnosni mehanizmi, međutim, uglavnom ne postoje.

Imajući u vidu značaj održivog razvoja prirodnih bogatstava, poput jezera i rijeka te prometnih infrastrukturnih objekata, poput cesta i željezničke infrastrukture, za svakodnevni život građana te gospodarstvo zemlje, valjalo bi više pažnje posvetiti problematici zaštite javnoga interesa vezanoga uz ta dobra. Predmet rada stoga je analiza pravnog režima raspolaganja javnim dobrom u općoj uporabi radi kritičkog preispitivanja primjerenosti hrvatskih pozitivnih propisa te predlaganja normativnih rješenja koja bi udovoljavala zahtjevima zaštite javnog interesa. U tom cilju najprije se razmatra ideja javnoga interesa u režimu javnoga dobra u općoj uporabi te se ukazuje na važnost koncepta javne namjene koja implicira korištenje dobra u svrhu zadovoljavanja javnih potreba društvene zajednice. U nastavku rada analiziraju se ograničenja ovlasti raspolaganja javnim dobrom u općoj uporabi, a koja čine temeljni mehanizam zaštite javnoga interesa u režimu toga dobra. Pritom se ističe važnost sustavnog normiranja zabrane otuđenja javnoga dobra, zabrane provedbe prisilnoga izvršenja nad javnim dobrom te zabrane stjecanja prava vlasništva javnoga dobra dosjelošću. Zatim se analiziraju dopušteni oblici raspolaganja javnim dobrom. Naglasak se stavlja na vrstu pravnih akata kojima se osniva posebna uporaba javnoga dobra, kao i na primjerenost njihova korištenja s gledišta zaštite javnoga interesa. Kao pravni naslovi posebne uporabe zasebno se razmatraju upravni akt, koncesija i ugovor.

3 Članak 35. stavak 1. Zakona o vlasništvu i drugim stvarnim pravima, Narodne novine, br. 91/96., 68/98., 137/99., 22/00., 73/00., 129/00., 114/01., 79/06., 141/06., 146/08., 38/09., 153/09., 143/12., 152/14. 


\section{JAVNI INTERES U PRAVNOM REŽIMU JAVNOGA DOBRA U OPĆOJ UPORABI}

Javni interes, kao interes koji je pravnom normom priznat društvenoj zajednici, u režimu javnoga dobra izražava se u vidu javne namjene. Javna namjena ima mnogobrojne implikacije, a ponajprije podrazumijeva gospodarenje javnim dobrom radi postizanja dobrobiti cjelokupne društvene zajednice, a ne samo određenog pojedinca ili grupe. Pritom se ponajprije misli na državu, kao organiziranu društvenu zajednicu, uređenu na osnovi pravila koja prihvaćaju (dobrovoljno ili pod prinudom) svi članovi. ${ }^{4}$ No, u obzir dolaze i druge društvene zajednice, neovisno o tomu jesu li određene po teritorijalnoj ili interesnoj osnovi. Javna namjena ključna je poveznica na kojoj se temelji jedinstveni pravni status za različite dijelove materijalnog svijeta koji zajednički čine javno dobro. Određivanjem javne namjene nekog dobra, tom se dobru ujedno dodjeljuje i konkretna javna svrha. U tom smislu Omejec navodi kako se javna namjena dodjeljuje određenom dobru radi pravne kvalifikacije toga dobra kao javnoga dobra, a tek iz toga posebnog svojstva dobra, iz normativno utvrđene javne svrhe, proizlazi njegovo korištenje koje se kvalificira kao opća uporaba. ${ }^{5}$ Konstitutivna je odrednica javnoga dobra, stoga, vezivanje različitih dijelova materijalnog svijeta istom javnom svrhom, sukladno kojoj korištenje takvog dobra treba ići u korist javnosti, odnosno građana. ${ }^{6}$

Javnoj namjeni, kao i načinima njezine konkretizacije u javnu svrhu, pridaje se značajna pažnja u pravnim sustavima koji normiraju institut javnoga dobra $u$ općoj uporabi. Francuski autori primjerice navode kako određivanje javne namjene predstavlja odluku o kvalifikaciji nekog dobra kao javnog dobra. Određivanje javne namjene može se provesti različitim vrstama pravnih akata. Tako se javna namjena, ovisno o vrsti dobra, može odrediti zakonom, podzakonskim općim aktom ili upravnim aktom. ${ }^{7}$ Koncept javne namjene kao izraza javnoga interesa u režimu javnoga dobra usvojilo je i njemačko pravo. Njemački autori pritom posebnu pozornost posvećuju aktu namjene (njem. Widmung). ${ }^{8}$ Aktom namjene javna namjena određenog dobra konkretizira se $u$ točno određenu javnu svrhu te se pritom nerijetko uređuju i druga pitanja bitna za status i režim javnoga dobra, tj. zemljišne čestice obuhvaćene javnopravnim statusom, način njegova korištenja, ograničenja opće uporabe, modaliteti osnivanja posebne uporabe, ovlasti i obveze vlasnika te upravitelja takvoga dobra itd. ${ }^{9}$ Akt namjene u Njemačkoj također može imati različite oblike. Tako u obzir

4 Vidi Visković, Nikola, Teorija države i prava, Zagreb, Birotehnika, 2001., str. 21.

5 Vidi Omejec, Jasna, Površinske tekuće vode kao dobro u općoj uporabi (osnove prava javnih stvari), doktorska disertacija, Zagreb, Pravni fakultet Sveučilišta u Zagrebu, 1993., str. 120.

6 Vidi Kromer, Michael, Sachenrecht des Offentlichen Rechts: Probleme und Grundlagen eines Allgemeinen Teils des Offentlichen Sachenrechts (Schriften zum Offentlichen Recht), Berlin, Duncker \& Humblot, 1985., str. 20.

7 Vidi Walline, Marcel, Droit administratif, 8. izd., Paris, Sirey, 1959., str. 890., Auby, J., Bon, P., op. cit., str. 45. do 46. i Gillet-Lorenzi, E., Traoré, S., op. cit., str. 50.

8 Teško je naći adekvatan prijevod za tako osebujan pojam kao što je Widmung u njemačkome pravu. Po našem mišljenju značenje ovog izraza najbolje je u hrvatski jezik prenijela Omejec nazvavši ga aktom namjene. Vidi Omejec, J., op. cit., str. 232.

9 Aktom namjene kojim se proglašava cesta određuje se, primjerice, radi li se o cesti namijenjenoj 
dolaze zakon, uredba, naredba i upravni akt. Najčešće je ipak riječ o upravnom aktu koji se donosi u vrlo kompleksnom upravnom postupku. Stupanjem na snagu akta namjene, dobro biva namijenjeno konkretnoj javnoj svrsi te stječe poseban status koji više nije reguliran samo normama građanskog prava, već se formira kao svojevrstan javnopravni status. ${ }^{10}$

Za razliku od francuskog i njemačkog prava, u hrvatskome pravu kvalifikacija određenog dijela materijalnog svijeta kao javnoga dobra ne sagledava se u svjetlu konkretizacije javne namjene, već samo s aspekta konstituiranja prava na opću uporabu. Vezivanje pravne kvalifikacije nekog dobra kao javnog uz konstituiranje opće uporabe, umjesto uz određivanje javne namjene u vidu konkretne javne svrhe, za posljedicu ima stavljanje javne namjene u službu opće uporabe, što je neispravno. Opća uporaba je uži pojam od javne namjene te u svojoj biti predstavlja jedan od mogućih pojavnih oblika javne svrhe koja je posljedica postojanja javnoga interesa. Osim opće uporabe, javna svrha nekog javnog dobra može se očitovati primjerice u korištenju od javnopravnih tijela, kao što je to slučaj s javnim dobrom u javnoj uporabi, ili pak u korištenju s ciljem ostvarivanja proračunskih prihoda osobe javnoga prava, kao što je to slučaj s financijskom imovinom. Opća uporaba stoga bi trebala biti u službi javne namjene, a ne obrnuto. Kvalitetno polazište za unaprjeđenje relevantnih pravnih odredbi možemo pronaći u Ustavu Republike Hrvatske. ${ }^{11}$ Sva javna dobra u hrvatskom pravnom sustavu ujedno imaju status dobara od interesa za Republiku Hrvatsku. Interes Republike Hrvatske temeljni je institut koji upućuje na primjenu pravila javnoga prava u režimu ovih dobara te kao takav predstavlja osnovu njihova posebnog pravnog statusa. Gavella definira interes Republike Hrvatske kao pravni standard kojim se označava pravom zaštićeni opći interes društvene zajednice kao cjeline na postizanju dobrobiti države i svih njezinih građana. ${ }^{12}$ Dakle, interes Republike Hrvatske je javni interes, koji se u režimu javnoga dobra izražava u vidu javne namjene. Daljnju konkretizaciju javne namjene nalazimo u Zakonu o vlasništvu i drugim stvarnim pravima kojim je, među ostalim, propisano kako je javno dobro u općoj uporabi ono koje je namijenjeno uporabi svih. ${ }^{13}$ Time se određivanje namjene ispravno stavlja u prvi plan, a uporaba svih kao opća uporaba u drugi plan. Shodno tomu, opća uporaba sagledava se kao pojavni oblik javne namjene.

Iz svega navedenog razvidno je kako u hrvatskome pravu postoji solidan temelj za normiranje javne namjene kao temeljne odrednice instituta javnoga dobra te opće uporabe kao njezina osnovnoga izraza. Taj koncept već je prepoznat u Ustavu te je konkretiziran Zakonom o vlasništvu i drugim stvarnim pravima. Cijelom konceptu

za promet motornih vozila, biciklističkoj stazi ili pješačkoj stazi. Ako je riječ o cesti namijenjenoj za promet motornih vozila tada se aktom namjene određuje njezin maksimalni kapacitet, dopuštena veličina i osovinsko opterećenje vozila, kao i najveća dopuštena brzina kretanja. Vidi Wolff, H. J., Bachof, O., Stober, R., op. cit., str. 688.

10 Ibid., str. 688. do 689.

11 Ustav Republike Hrvatske, Narodne novine, br. 56/90., 135/97., 8/98., 113/00., 124/00., 28/01., 41/01., 55/01., 76/10., 85/10. - pročišćeni tekst, 5/14.

12 Vidi Gavella, Nikola ... [et al.], Stvarno pravo - posebna pravna uređenja, Zagreb, Narodne novine, 2011., str. 9.

13 Članak 35. stavak 4. Zakona o vlasništvu i drugim stvarnim pravima. 
morali bi stoga biti prilagođeni i posebni zakoni, posebno Zakon o vodama, ${ }^{14}$ Zakon o cestama ${ }^{15}$ i Zakon o željeznici. ${ }^{16}$ Prilagodba relevantnog zakonodavstva iznimno je važno, jer izostanak adekvatne normativne valorizacije javne namjene kao okosnice javnopravnog režima javnoga dobra u općoj uporabi uzrokuje mnogobrojne negativne posljedice po zaštitu javnoga interesa. Posljedice su najvidljivije u režimu raspolaganja javnim dobrom, u kojemu je došlo do značajnog upliva instituta privatnog prava. Zbog nepostojanja odgovarajućih mehanizama zaštite javnoga interesa, primjena instituta privatnoga prava u raspolaganju javnim dobrom u općoj uporabi može rezultirati pravnim učincima koji su protivni njegovoj javnoj svrsi i ugrožavaju interes društvene zajednice.

\section{OBLICI ZAŠTITE JAVNOGA INTERESA U REŽIMU JAVNOGA DOBRA U OPĆOJ UPORABI}

Javnopravni status javnoga dobra u općoj uporabi očituje se u određenim pozitivnim i negativnim učincima imanentnima vlasničkopravnom režimu toga dobra. Pozitivni učinci ogledaju se u tomu da je javno dobro u općoj uporabi objekt vlasništva osoba javnog prava, što podrazumijeva da ovlast za donošenje statusnih odluka i odluka o raspolaganju, kao i odgovornost za provođenje djelatnosti upravljanja, ulaze u djelokrug javne uprave i tijela vlasti. Negativni učinci očituju se u ograničenju privatnopravnih raspolaganja javnim dobrom, što uključuje zabranu raspolaganja koje bi rezultiralo ograničenjem, odnosno isključenjem javne svrhe javnoga dobra.

Kao što je ranije istaknuto, javni interes u režimu javnoga dobra u općoj uporabi očituje se u pravu svih pripadnika društvene zajednice da to dobro koriste sukladno njegovoj namjeni kako bi time zadovoljili svoje potrebe. Zadovoljavanje javnih potreba odvija se kao generalno i ravnopravno korištenje javnoga dobra od strane građana $i$ drugih subjekata prava, koje se naziva općom uporabom. Opća uporaba, dakle, temeljni je oblik korištenja javnoga dobra i njegova osnovna javna svrha. ${ }^{17}$ Zaštita javnog interesa vezanoga uz javno dobro zbog toga podrazumijeva zaštitu opće uporabe. Mjere zaštite posebno se poduzimaju u odnosu na samo javno dobro, kako bi se očuvala ona obilježja zbog kojih je to dobro dano na ravnopravno i slobodno korištenje svima. Temeljni preduvjet učinkovitosti takve zaštite, vlasništvo je osobe javnog prava nad javnim dobrom. Poglavito je riječ o državi i teritorijalnim jedinicama kao pravnim osobama koje ostvaruju javne ciljeve i interese. ${ }^{18} \mathrm{U}$ europskim

14 Zakon o vodama, Narodne novine, br. 153/09., 63/11., 130/11., 56/13., 14/14.

15 Zakon o cestama, Narodne novine, br. 84/11., 22/13., 54/13., 148/13., 92/14.

16 Zakon o željeznici, Narodne novine, br. 94/13., 148/13.

17 Omejec na primjeru opće uporabe voda ističe kako je taj način korištenja neovisan o povijesnim, društvenim i gospodarskim temeljima pojedinih pravnih sustava. Nije postojao i ne postoji niti jedan pravni poredak koji ne bi poznavao i priznavao pravo na opću uporabu voda. Krajem 19. stoljeća države su na sveobuhvatan način regulirale pravo na opću uporabu ovog prirodnog javnog dobra. Još je Bogišić isticao kako bi bunar iz kojega se ne bi moglo zahvaćati vodu: "presahnuo od nepravde, jer je voda božja." Omejec, J., op. cit., str. 116. do 117.

18 Pravne osobe mogu se podijeliti na osobe javnog prava i osobe privatnog prava, što je posljedica cjelokupne diobe prava na javno i privatno. Kao kriterij razlikovanja javljaju se 
kontinentalnim pravnim poredcima najveći dio javnih dobara nalazi se u državnome vlasništvu. ${ }^{19}$ Države u svojem vlasništvu zadržavaju sva dobra od strateškog značaja, neovisno o tomu ogleda li se taj značaj u prometnom, gospodarskom ili kakvom drugom državnom interesu. Manji dio javnih dobara uz koje nije neposredno vezan državni interes, a koja su pritom od interesa za lokalnu ili regionalnu zajednicu prepušta se $\mathrm{u}$ vlasništvo teritorijalnim jedinicama. ${ }^{20}$ Među brojnim razlozima za specifičan vlasničkopravni režim javnoga dobra u općoj uporabi posebno se ističe sposobnost osoba javnog prava da zaštite javni interes kojeg društvena zajednica ima u pogledu toga dobra. Načelno se smatra kako javno dobro u općoj uporabi ne bi smjelo biti objektom vlasništva osoba privatnog prava. Osoba privatnog prava mogla bi monopolizirati korištenje javnoga dobra u općoj uporabi čime bi osujetila njegovu javnu svrhu. Osim toga, osoba privatnog prava ne može zaštititi javni interes u pogledu javnoga dobra u općoj uporabi čak i da to želi, jer ne ne raspolaže monopolom legitimne fizičke prisile. Prema Pusiću, regulacija ponašanja u društvu vrši se propisima čije poštovanje u krajnjem slučaju jamči upravo monopol primjene fizičke sile, a koji prvenstveno pripada državi. ${ }^{21}$ Vlasništvo osobe javnoga prava nad javnim dobrom u općoj uporabi predstavlja, stoga, imperativ zaštite javnoga interesa vezanoga uz to dobro, neovisno o tomu izražava li se taj interes kao državni, regionalni ili lokalni.

Radi zaštite specifičnog vlasničkopravnog poretka, države kao temeljni vlasnici javnoga dobra samoograničavaju se u obavljanju vlasničkih ovlasti, ponajprije ovlasti raspolaganja javnim dobrom. Tim ograničenjima ujedno su obvezane i teritorijalne jedinice koje su vlasnici javnoga dobra. Neke države tako izričito propisuju zabranu otuđenja javnoga dobra u općoj uporabi. U državama u kojima takva zabrana nije izričito propisana ona se faktično provodi zbog posrednih ograničenja u raspolaganju

cilj i zadaća pravne osobe. Stoga se u osobe javnog prava svrstavaju one pravne osobe koje ostvaruju javne ciljeve i interese, dok se u osobe privatnog prava svrstavaju one pravne osobe koje slijede privatne ciljeve i interese. Država i teritorijalne jedinice nisu jedine osobe javnog prava. Osobama javnog prava smatraju se i neke druge pravne osobe, prvenstveno one koje ostvaruju javni interes i ciljeve te se pritom financiraju iz proračuna, poput određenih trgovačkih društava. Vidi Klarić, Petar, Vedriš, Marin, Građansko pravo: opći dio, stvarno pravo, obvezno i nasljedno pravo, 14. izd., Zagreb, Narodne novine, 2014., str. 53. Za potrebe ovoga rada pojam osoba javnog prava koristi se u nešto užem smislu te se njime označavaju država i teritorijalne jedinice kao vlasnici javnog dobra u općoj uporabi. U tom smislu, pojam osoba javnoga prava podudara se s istovjetnim pojmom koji se u Zakonu o uređivanju imovinskopravnih odnosa $u$ svrhu izgradnje infrastrukturnih građevina koristi za označavanje države i teritorijalnih jedinica kao vlasnika infrastrukturnih građevina prometne, javne, komunalne i druge infrastrukture poput cesta, vodnih građevina, komunalnih objekata i željezničke infrastrukture. Članci 1. i 3. Zakona o uređivanju imovinskopravnih odnosa u svrhu izgradnje infrastrukturnih građevina, Narodne novine, br. 80/11. Za označavanje širega kruga subjekata koji obavljaju javne zadaće, ponajprije zadaće upravljanja javnim dobrom u općoj uporabi, koristi se izraz subjekti javnog prava.

19 Vidi Popovski, Aleksandra, Upravnopravni aspekti upravljanja i korištenja javnoga dobra u općoj uporabi, doktorska disertacija, Zagreb, Pravni fakultet Sveučilišta u Zagrebu, 2016., str. 75. do 79 .

20 Ibid., str. 80. do 86.

21 Pusić, Eugen, Društvena regulacija, Granice znanosti i iskustva, Zagreb, Pravni fakultet Sveučilišta u Zagrebu, 1989., str. 70. do 71. 
javnim dobrom, posljedično kojima to dobro uživa status gotovo jednak statusu dobra izvan pravnoga prometa. Zabrana otuđenja javnoga dobra u općoj uporabi izričito je propisana u državama koje su usvojile koncept javnoga vlasništva, poput Francuske, Italije i Srbije. ${ }^{22}$ Štoviše, u navedenim državama dodatno je određena i zabrana provedbe prisilnog izvršenja nad javnim dobrom u općoj uporabi. Javno dobro tako ne smije biti opterećeno stvarnopravnim osiguranjima tražbina, ne smije biti predmetom ovrhe niti nad njime neka osoba smije steći pravo vlasništva temeljem izvršenja. Kako bi se u cijelosti isključila svaka mogućnost prestanka vlasništva osobe javnoga prava nad javnim dobrom u općoj uporabi, u odnosu na to dobro u cijelosti je zabranjeno originarno stjecanje prava vlasništva dosjelošću. ${ }^{23} \mathrm{U}$ državama koje režim javnoga dobra u općoj uporabu nisu utemeljile na konceptu javnoga vlasništva, zaštita javnog interesa ostvaruje se zabranom privatnopravnih raspolaganja koja bi potencijalno mogla ograničiti ili isključiti javnu svrhu toga dobra. Tako je primjerice u njemačkom, austrijskom i slovenskom pravu vlasnik javnog dobra u općoj uporabi u izvršavanju svojih vlasničkih ovlasti ograničen onoliko koliko je potrebno da bi dobro služilo javnoj svrsi koja mu je dodijeljena. Detaljnija analiza pravnog režima pojedinih pojavnih oblika javnoga dobra u općoj uporabi ukazuje na to da je pravo vlasništva uslijed snažnih javnopravnih ograničenja redovito svedeno na golo pravo (lat. nudum ius). Posljedično tomu, iako javno dobro u općoj uporabi formalnopravno nije isključeno iz pravnog prometa, zbog pravila o ništetnosti privatnopravnih raspolaganja koja ugrožavaju opću uporabu, ta dobra faktično uživaju status vrlo sličan onomu res extra commercium. Posljedica navedenoga pravnog pristupa faktična je nemogućnost osobe javnoga prava da otuđi javno dobro u općoj uporabi. Taj specifični koncept vlasništva javnoga dobra u njemačkome pravu opravdano se naziva modificiranim privatnim vlasništvom, pri čemu relevantni autori često ističu kako javno dobro ne smije biti u cijelosti objektom građanskopravnog režima zbog svoje javne namjene i važnosti za društvenu zajednicu. ${ }^{24} \mathrm{U}$ prilog navedenome govori i Omejec, naglašavajući kako je Njemačka sebi pridržala opsežne ovlasti u pogledu javnoga dobra u općoj uporabi, što ukazuje kako osnovna ideja relevantnih njemačkih zakona pripada javnom pravu i da odstupanja koja u takvoj regulativi postoje u odnosu na pravo država u kojima je uspostavljeno javno vlasništvo leže više u formi negoli u sadržaju. ${ }^{25}$

22 Vidi članak L 3111-1 francuskog Općeg zakona o vlasništvu osoba javnoga prava (fra. Code general de la propriete des personnes publiques), službeni pročišćeni tekst dostupan na:

https://www.legifrance.gouv.fr/affichCode.do?cidTexte=LEGITEXT000006070299\&dateTexte $=20080505$ (16.12.2016.), članak 823. talijanskog Građanskog zakonika (tal. Codice civile), Gazzetta Ufficiale, n. 79/42., zadnja izmjena n. 202/16. i članak 16. srpskog Zakona o javnom vlasništvu (srp. Zakon o javnoj svojini), Službeni glasnik Republike Srbije, br. 72/11., 88/13., 105/14.

23 Vidi članke L 3111-1 i L 2311-1 francuskog Općeg zakona o vlasništvu osoba javnoga prava, članak 823. talijanskog Građanskog zakonika te članke 16. i 17. srpskog Zakona o javnom vlasništvu.

24 Vidi Wolff, H. J., Bachof, O., Stober, R., op. cit., str. 679, Antoniolli, Walter, Koja, Friedrich, Allgemeines Verwaltungsrecht, Wien, Manzsche Verlags- und Universitätsbuchhandlung, 1996., str. 698. i Virant, Gregor, Pojem in pravni režim javnega dobra, Univerza v Ljubljani, Pravna fakulteta, 1990., str. 80. do 87.

25 Omejec, J., op. cit., str. 78. do 79. Slično vidi u Gavella, Nikola ... [et al.], Stvarno pravo - 
Režim obavljanja vlasničkih ovlasti nad javnim dobrom u općoj uporabi u hrvatskome pravu ne može se u cijelosti uklopiti niti u jedan od navedenih koncepata. Pravni sustav Republike Hrvatske ne poznaje koncept javnoga vlasništva, stoga se vlasništvo osoba javnoga prava po pravnoj prirodi ne razlikuje od vlasništva osoba privatnoga prava. Zakonom o vlasništvu i drugim stvarnim pravima izričito je propisano kako Republika Hrvatska i druge osobe javnoga prava koje su nositelji prava vlasništva imaju kao vlasnici u pravnim odnosima jednak položaj kao i privatni vlasnici, ako posebnim zakonom nije što drugo određeno. ${ }^{26} \mathrm{U}$ Hrvatskoj ne postoji zakon kojim bi na općenit način bio normiran pravni režim javnoga dobra u općoj uporabi. ${ }^{27}$ Pravni okvir raspolaganja tim dobrom stoga prije svega čine Zakon o vodama, Zakon o cestama te Zakon o željeznici. Na sva pitanja koja nisu uređena nekim od navedenih zakona supsidijarno se primjenjuju propisi kojima je uređeno raspolaganje državnom imovinom, osobito Zakon o upravljanju i raspolaganju imovinom u vlasništvu Republike Hrvatske. ${ }^{28}$ Zakonom o vodama izričito je propisano kako se javno vodno dobro nalazi u vlasništvu Republike Hrvatske te kako iz toga vlasništva ne smije biti otuđeno. ${ }^{29}$ Povrh toga, na javnome vodnom dobru ne može se steći pravo vlasništva dosjelošću, niti se to dobro smije opteretiti založnim pravom. ${ }^{30}$ Osim toga, država je samu sebe, kao i teritorijalne jedinice, ograničila i po pitanju otuđenja cesta. Zakonom o cestama propisano je da se javne ceste ne mogu otuđiti iz vlasništva Republike Hrvatske. ${ }^{31}$ Istim Zakonom također je propisano da se nerazvrstane ceste ne mogu otuđiti iz vlasništva jedinica lokalne samouprave. ${ }^{32}$ Zabrana stjecanja vlasništva ceste dosjelošću nije izričito propisana Zakonom o cestama, ali smatramo kako proizlazi iz tumačenja odredbi kojima je regulirano stjecanje stvarnih prava na cesti. Zakonom o cestama tako je propisano da se na cestama ne mogu stjecati stvarna prava, osim u slučajevima određenima tim Zakonom. Jedina stvarna prava koja se prema zakonskim odredbama mogu uspostaviti na cesti su pravo građenja i pravo služnosti. ${ }^{33} \mathrm{Iz}$

svezak 1., Zagreb, Narodne novine, 2007., str. 141.

26 Članak 1. stavak 2. i članak 35. stavak 1. Zakona o vlasništvu i drugim stvarnim pravima.

27 Dodatnu pomutnju izaziva odredba Zakona o vlasništvu i drugim stvarnim pravima kojom je određeno da se na pravni režim javnog dobra u općoj uporabi na odgovarajući način primjenjuju pravila koja vrijede za opće dobro. Članak 35. stavak 4. Zakona o vlasništvu i drugim stvarnim pravima. Potpuno je nejasno koja su to pravila i gdje su ona navedena, kada u Zakonu o vlasništvu i drugim stvarnim pravima ne postoje odredbe koje bi na općenit način uređivale ovu tematiku. Povrh toga, u hrvatskom pravnom sustavu ne postoji niti zakon koji bi na općenit način uređivao pravni režim općega dobra. Posebni zakoni po tom su pitanju podnormirani, jer uređuju samo specifičnu problematiku vezanu uz pojedinu kategoriju općeg dobra. Nejasno je na koji način bi se pravna pravila kojima je uređen režim pojedinih općih dobara trebala primijeniti na pitanja koja se tiču vlasničkih ovlasti raspolaganja javnim dobrom u općoj uporabi, imamo li u vidu okolnost da opće dobro nije sposobno biti objekt prava vlasništva. Članak 3. stavak 2. Zakona o vlasništvu i drugim stvarnim pravima.

28 Zakon o upravljanju i raspolaganju imovinom u vlasništvu Republike Hrvatske, Narodne novine, br. 94/13., 18/16.

29 Članak 11. stavci 4. i 5. Zakona o vodama.

30 Članak 11. stavak 6. i članak 13. Zakona o vodama.

31 Članak 3. stavak 6. Zakona o cestama.

32 Članak 101. Zakona o cestama.

33 Članak 3. Zakona o cestama. 
navedenoga proizlazi da se ceste ne mogu otuđiti iz vlasništva Republike Hrvatske te da se na njima mogu ostvariti samo dva taksativno navedena ograničena stvarna prava. Sustavnost navedenog koncepta neotuđivosti javnoga dobra u općoj uporabi narušena je, međutim, Zakonom o željeznici. Potonjim Zakonom nije izričito propisana zabrana otuđenja željezničke infrastrukture. S obzirom na to da je željeznička infrastruktura imovina u vlasništvu Republike Hrvatske, na pitanje njezina otuđenja supsidijarno se primjenjuje Zakon o upravljanju i raspolaganju imovinom u vlasništvu Republike Hrvatske, kojim također nije propisana zabrana otuđenja. ${ }^{34}$ Postavlja se pitanje je li zakonodavac iz Zakona o željeznici namjerno izostavio odredbu o neotuđivosti toga dobra ili je riječ o propustu koji je posljedica nepostojanja općeg pravnog režima javnoga dobra u općoj uporabi te nedovoljne suradnje nadležnih tijela pri donošenju posebnih zakona. Skloniji smo prikloniti se drugo navedenom stavu. Smatramo kako neotuđivost željezničke infrastrukture, iako nije izričito propisana, proizlazi iz tumačenja odredbi Zakona o željeznici kojima je uređeno ukidanje statusa javnoga dobra. Zakonom o željeznici tako je propisano da se dijelu željezničke infrastrukture za koji ne postoji javni interes i interes korisnika usluga željezničkog prijevoza ili na kojem je trajno obustavljen željeznički prijevoz može oduzeti status javnog dobra u općoj uporabi. Odluku o trajnoj obustavi željezničkog prijevoza i oduzimanju statusa javnog dobra u općoj uporabi željezničkoj infrastrukturi donosi Vlada Republike Hrvatske. Propisano je i kako Vlada Republike Hrvatske može dio željezničke infrastrukture kojem je oduzet status javnog dobra u općoj uporabi prenijeti na drugog korisnika ili ovlastiti upravitelja infrastrukture na poduzimanje pravnih poslova u svezi s njegovim daljnjim statusom i namjenom. ${ }^{35}$ Iz navedene odredbe proizlazi kako se dio željezničke infrastrukture može otuđiti tek po prestanku statusa javnoga dobra u općoj uporabi. Primjenom argumenta a contrario, željeznička infrastruktura kojoj nije prestao status javnoga dobra u općoj uporabi ne smije se otuđiti. Smatramo kako bi neotuđivost željezničke infrastrukture de lege ferenda ipak valjalo izričito propisati zakonom. Sve dok opći pravni režim javnoga dobra u općoj uporabi nije reguliran zakonom koji bi se u tom području primjenjivao kao lex generalis, takva zabrana trebala bi biti sadržana u Zakonu o željeznici.

Raspolaganje javnim dobrom u općoj uporabi, unatoč velikim ograničenjima, ipak nije u cijelosti onemogućeno. Javno dobro formirano prirodnim putem važan je resurs i prirodno bogatstvo, čija namjena zahvaljujući njegovim bogatim potencijalima može biti i kakva druga javna svrha, ne samo opća uporaba. Pojedine države raspolažu značajnim prirodnim bogatstvima, a nisu ih u mogućnosti koristiti u vlastitoj režiji zbog nedostatnih financijskih sredstava, tehničke opremljenosti, nedostatka specifičnog know-howa ili kakva drugog razloga. ${ }^{36} \mathrm{~S}$ druge strane, umjetno javno dobro u općoj uporabi često se gradi radi obavljanja funkcije prometne infrastrukture. Osnovni oblik opće uporabe prometnih infrastrukturnih objekata sastoji se u prometovanju različitim tipovima vozila s motornim pogonom. Suvremeni brzi tehnološki razvoj zahtijeva

34 Članci 11. i 12. Zakona o željeznici te članak 4. stavak 1. točka 7. Zakona o upravljanju i raspolaganju imovinom u vlasništvu Republike Hrvatske.

35 Članak 13. Zakona o željeznici.

36 Đerđa, Dario, Upravnopravni aspekti koncesija, doktorska disertacija, Split, Pravni fakultet Sveučilišta u Splitu, 2005., str. 1. 
kontinuirano unaprjeđivanje sigurnosti tog modaliteta korištenja javnoga dobra, nerijetko povećanjem raznolikosti i obujma popratnih usluga koje se pružaju na javnome dobru. U tu svrhu potrebno je izvesti određene infrastrukturne poduhvate, za koje osoba javnoga prava ponekad nema dovoljno materijalnih sredstava. Obavljanje tih poduhvata stoga se može povjeriti drugoj osobi koja raspolaže odgovarajućim kapitalom. Zainteresirani poduzetnik time dobiva mogućnost koristiti dio javnoga dobra u cilju ostvarenja dobiti. Korisnici javnoga dobra pritom dobivaju mogućnost korištenja određene usluge, a osoba javnoga prava po proteku roka u kojem je poduzetnik imao pravo iskorištavati dio javnoga dobra stječe izgrađeni infrastrukturni objekt u svoje vlasništvo. ${ }^{37}$ Pravni sustavi koji su normirali institut javnoga dobra u općoj uporabi zbog toga redovito dopuštaju određene modalitete raspolaganja tim dobrom. Raspolaganje javnim dobrom usmjereno je osnivanju specifičnih oblika korištenja toga dobra koji se ne mogu podvesti pod opću uporabu, radi ostvarivanja različitih, osobito gospodarskih interesa.

\section{RASPOLAGANJE JAVNIM DOBROM U OPĆOJ UPORABI}

Raspolaganje javnim dobrom u općoj uporabi podrazumijeva donošenje pravnih akata, odnosno sklapanje pravnih poslova kojima se osniva posebna uporaba toga dobra. Posebna uporaba individualizirani je oblik korištenja javnoga dobra koji nadilazi opću uporabu, uslijed čega redovito dolazi do ograničenja ili isključivanja opće uporabe drugih subjekata. Posebna uporaba kao ograničenje opće uporabe može biti neznatnoga karaktera te kao takva jedva primjetna subjektima opće uporabe, ali može biti i bitna, čak u toj mjeri da na dugo vremensko razdoblje u cijelosti onemogući opću uporabu. Zbog toga se posebna uporaba uvijek temelji na dozvoli koju dodjeljuje subjekt javnoga prava koji upravlja javnim dobrom. ${ }^{38}$ Njemački autori ističu kako se posebna uporaba od opće razlikuje u formalnom i materijalnom smislu. U formalnom smislu za odvijanje opće uporabe nije potrebno posebno dopuštenje, dok je za posebnu uporabu potrebno ishoditi dozvolu. ${ }^{39} \mathrm{U}$ materijalnom smislu, opća uporaba predstavlja izraz osobnog i gospodarskog samoodređenja, dok posebna uporaba predstavlja subjektivno javno pravo pojedinca. ${ }^{40}$ Francuska teorija o posebnoj uporabi govori u smislu isključivog korištenja dijela javnoga dobra radi ostvarivanja kakve koristi. ${ }^{41}$ Ekskluzivnost takvoga korištenja predstavlja negiranje javne svrhe javnoga dobra, stoga je zakonom određeno kako nitko ne smije zauzeti ili koristiti javno dobro na način koji nadilazi opću uporabu bez dozvole. ${ }^{42}$

Svatko tko želi koristiti javno dobro na način koji nadilazi opću uporabu obvezatan je, dakle, ishoditi odgovarajuću dozvolu. Kada govorimo o dozvoli, podrazumijevamo dozvolu u materijalnom smislu riječi kao dopuštenje koje daje osoba javnoga prava, neovisno o tomu daje li se ono u formi jednostranog ili

37 Ibid., str. 2.

38 Vidi Gillet-Lorenzi, E., Traoré, S., op. cit., str. 105. i Papier, H., op. cit., str. 113.

39 Vidi Wolff, H., Bachof, O., Stober, R., op. cit., str. 683. do 686.

40 Vidi Omejec, J., op. cit., str. 111.

41 Vidi Gillet-Lorenzi, E., Traoré, S., op. cit., str. 98. do 99.

42 Članak L2122-1 francuskog Općeg zakona o vlasništvu osoba javnog prava. 
dvostranog pravnog akta. Korištenje javnoga dobra na način koji nadilazi opću uporabu bez odgovarajuće dozvole nije dopušteno i kvalificira se kao prekršaj. Jedno od najvažnijih pitanja posebne uporabe je pravna priroda dozvole kojim se takav oblik korištenja javnoga dobra odobrava. U tom kontekstu ističemo kako su, radi obveze osobe javnoga prava da zaštiti javno dobro, u režim raspolaganja javnim dobrom implementirani specifični mehanizmi zaštite. Najvažniji među njima su vremenska ograničenost dozvole za posebnu uporabu te ovlast osobe javnoga prava da dozvolu opozove ${ }^{43}$ Neovisno o formi u kojoj je dana, dozvola za posebnu uporabu uvijek se izdaje na određeno vremensko razdoblje. Kako je javno dobro u općoj uporabi izvorno namijenjeno uporabi svih, odstupanja od načela slobode korištenja mogu biti samo privremene naravi. Trajni prijenos prava na posebnu uporabu javnoga dobra bio bi protivan pravnoj prirodi instituta javnoga dobra u općoj uporabi. Stoga se dozvola uvijek izdaje na određeni rok. Po proteku roka, dozvola prestaje vrijediti i na javnom dobru ponovno se uspostavlja opća uporaba u svom punom opsegu. ${ }^{44}$ Protek roka na koji je dozvola dodijeljena nije, međutim, jedini razlog za prestanak posebne uporabe. Posebna uporaba prestaje i opozivom dozvole. Opoziv dozvole za posebnu uporabu obavlja se donošenjem novog pravnog akta kojim se ukida pravni naslov posebne uporabe. Time se pravni naslov posebne uporabe stavlja izvan snage ex nunc, čime se onemogućuje njegovo daljnje pravno djelovanje. ${ }^{45}$ Jedna od najvažnijih zadaća osobe javnoga prava zaštita je javnog interesa vezanoga uz javno dobro. Ona stoga mora moći opozvati dozvolu za posebnu uporabu onog trenutka kada je takav način korištenja javnoga dobra počeo ugrožavati javni interes (primjerice u slučaju prestanka izvršavanja obveza od strane ovlaštenika posebne uporabe). Ovo je pravilo neizmjerno važno ako imamo na umu da javno dobro svakodnevno upotrebljavaju mnogobrojni pripadnici društvene zajednice te da već vrlo mala odstupanja od pravila zaštite i očuvanja toga dobra mogu prouzročiti veliku opasnost po ljudski život i zdravlje. Stoga, ako po zasnivanju posebne uporabe nastupe okolnosti zbog kojih subjekt koji upravlja javnim dobrom procijeni kako bi s aspekta zaštite javnog interesa bilo nužno opozvati dozvolu, on je ovlašten to i učiniti.

U poredbenom pravu velika se važnost pridaje ovlasti osobe javnoga prava da jednostranim i autoritativnim zahvatom u prava ovlaštenika posebne uporabe opozove dozvolu za posebnu uporabu kada to smatra nužnim te da odluka o opozivu proizvodi pravni učinak od trenutka njezina donošenja. Da bi takvo što bilo moguće, nužno je odnos osobe javnoga prava i ovlaštenika posebne uporabe koncipirati kao upravnopravni odnos. Dozvola za posebnu uporabu zbog toga je redovito upravni akt ili koncesija. Upravnopravni odnos posebne uporabe implicira subordinirani položaj ovlaštenika posebne uporabe i šire ovlasti osobe javnoga prava tijekom cjelokupnog trajanja toga odnosa ${ }^{46} \mathrm{U}$ Francuskoj i ostalim državama koje su usvojile koncept javnoga vlasništva, javnim dobrom u općoj uporabi raspolaže se isključivo upravnim aktom ili koncesijom. U Njemačkoj i ostalim državama koje su usvojile model

43 Vidi Gillet-Lorenzi, E., Traoré, S., op. cit., str. 108.

44 Vidi Auby, J., Bon, P., op. cit., str. 94.

45 Vidi Đerđa, D., op. cit., str. 81.

46 Ibid., str. 58. do 59. 
modificiranog privatnog vlasništva, dozvola za posebnu uporabu uglavnom ima oblik upravnoga akta ili koncesije. Iznimno, ako posebna uporaba ne isključuje, odnosno ne ograničava opću uporabu, pravo na posebnu uporabu može biti utemeljeno i ugovorom građanskoga prava. S obzirom na okolnost da većina oblika posebne uporabe na neki način ograničava ili isključuje opću uporabu, slučajevi raspolaganja javnim dobrom ugovorima građanskoga prava nisu česti.

U hrvatskome pravu pitanje pravne prirode dozvole za posebnu uporabu nije adekvatno niti sustavno uređeno. Javnopravni instrumenti podzastupljeni su u većini posebnih zakona, a ostali vidovi raspolaganja javnim dobrom ne vode se u dostatnoj mjeri zaštitom javnoga interesa. Takva situacija otvara prostor za unaprjeđenje režima raspolaganja javnim dobrom, zbog čega se u nastavku rada zasebno analiziraju temeljni pravni akti, odnosno pravni poslovi, koji se javljaju kao pravni naslovi posebne uporabe.

\subsection{Upravni akt}

Upravni akt kao autoritativno odlučivanje sa svrhom izazivanja neposrednog pravnog učinka u konkretnoj upravnoj stvari ${ }^{47}$ temeljni je pravni institut koji se koristi u svrhu raspolaganja javnim dobrom. Pritom valja imati na umu kako se u pravno-teorijskim krugovima različitih država pojam upravni akt ne koristi uvijek dosljedno. ${ }^{48}$ Ovaj se pojam na različite načine širi ili sužava te se njime nerijetko označavaju različiti akti uprave. Kada govorimo o upravnom aktu koji je pravna osnova posebne uporabe, tada valja imati u vidu kako je riječ o jednostranoj i autoritativnoj odluci donesenoj u konkretnoj upravnoj stvari kojom javnopravno tijelo u okviru ovlasti povjerenih zakonom, primjenom materijalnih normi upravnog prava rješava o pravima, obvezama ili pravnim interesima pojedinca. ${ }^{49} \mathrm{Zbog}$ obilježja kao što su jednostranost, autoritativnost, pravno djelovanje, konkretnost i pravna vezanost, upravni akt predstavlja temeljni instrument kojim osoba javnoga prava odlučuje o pravima i obvezama ovlaštenika posebne uporabe. Dozvola kojom se dodjeljuje pravo na posebnu uporabu nastaje kao posljedica izražene autoritativne volje osobe javnoga prava. Subjekt koji je aplicirao za dodjelu prava na posebnu uporabu nije ovlašten s osobom javnoga prava pregovarati oko postojanja pretpostavki za dodjelu dozvole. Inicijativa stranke da joj se dodijeli pravo na posebnu uporabu

47 Vidi Krbek, Ivo, Upravni akt, Zagreb, Jugoslavenska akademija znanosti i umjetnosti, 1957. str. 16.

48 Ivančević u tom smislu navodi kako teorija nije uspjela razviti opće prihvatljivu definiciju upravnog akta. Navedeno može biti posljedica izvođenja pojma upravnog akta iz različitih pravno-političkih načela i situacija koje nisu nužno ni pravno niti faktično prikladne za takvu dedukciju. S druge strane, to može biti posljedica preuveličavanja određenih obilježja upravnog akta, kao što je, primjerice Hauriou prenaglasio svojstvo izvršnosti upravnog akata i nazvao ga izvršnom odlukom (fra. decision executoire). Povrh svega, zakonodavac često iz određenih političko-oportunističkih razloga odstupa od uvjetno priznate definicije koju je ponudila teorija i razvija vlastitu, zakonsku, definiciju koju onda zbog njezine neodređenosti pravna praksa nerijetko širi ili sužava, ovisno o potrebama. Ivančević, Velimir, Institucije upravnog prava, knjiga 1., Zagreb, Pravni fakultet Sveučilišta u Zagrebu, 1983., str. 231.

49 Vidi Borković, Ivo, Upravno pravo, 7. izd., Zagreb, Narodne novine, 2002., str. 360. 
predstavlja samo postupovnu pretpostavku počeka upravnog postupka. Posljedično autoritativnosti upravnog akta, volja stranke nije mjerodavna pri donošenju dozvole za posebnu uporabu..$^{50}$ Donošenjem upravnog akta, između osobe javnoga prava i ovlaštenika posebne uporabe uspostavlja se upravnopravni odnos. Osoba javnoga prava u upravnopravnom odnosu istupa s jačom voljom te se nalazi u nadređenom položaju spram ovlaštenika posebne uporabe. Jednostrano izražena volja osobe javnoga prava, posljedično njezinom autoritativnom položaju, sankcionira se uporabom sredstava prinude u slučaju izostanka dobrovoljnog izvršenja obveza ovlaštenika posebne uporabe. ${ }^{51}$ Važno obilježje dozvole za posebnu uporabu je i njezin neposredni pravni učinak. Tom dozvolom u korist ovlaštenika posebne uporabe osnivaju se određena prava, ali i obveze koje on prije njezina donošenja nije imao. Osnivanjem upravnopravnog odnosa mijenja se dotadašnji pravni status adresata dozvole. Pravno djelovanje dozvole za posebnu uporabu pritom je usmjereno na konkretno javno dobro te se javlja primarno između osobe javnoga prava koja je dozvolu izdala te individualno određenog ovlaštenika posebne uporabe. Na taj način dozvola za posebnu uporabu izaziva neposredan pravni učinak u konkretnoj upravnoj stvari. Valja naglasiti kako djelovanje dozvole za posebnu uporabu nije ograničeno samo na subjekte tog upravnopravnog odnosa. Djelovanje navedene dozvole proteže se i na sve druge subjekte koji pod njezin učinak dolaze u situaciji kada svojim ponašanjem diraju u subjektivno javno pravo ovlaštenika posebne uporabe. ${ }^{52}$ Konačno, osoba javnog prava pri donošenju dozvole za posebnu uporabu vezana je načelom zakonitosti. Ona djeluje u ulozi neposrednog izvršitelja općih normativnih akata, pa je pri zasnivanju upravnopravnog odnosa vezana i voljom zakonodavca i voljom donosioca podzakonskih općih akata koji se primjenjuju u konkretnoj upravnoj stvari. ${ }^{53}$ Osoba javnoga prava dozvolu smije izdati samo ako je to u okviru njezine nadležnosti, provodeći pravila upravnog postupka, pod uvjetima utvrđenim materijalnim pravom te u propisanom obliku. ${ }^{54}$

Široka primjena upravnoga akta u raspolaganju javnim dobrom posljedica je još jedne, iznimno važne okolnosti, a to je ovlast osobe javnoga prava da naknadno utječe na već osnovani upravnopravni odnos. Kada je upravnim aktom osnovano pravo na posebnu uporabu, osoba javnoga prava time nije iscrpila sve svoje ovlasti. Naprotiv, ona nad posebnom uporabom obavlja stalan nadzor, koji pod određenim uvjetima može rezultirati ukidanjem prava na posebnu uporabu. Pritom nije riječ o poništavanju upravnog akata koji je pravni naslov posebne uporabe zbog određenih nezakonitosti vezanih uz njegovo donošenje za koje se nije znalo u trenutku donošenja, nego o ovlasti osobe javnoga prava da samostalnim upravnim aktom (lat. actus contrarius), donesenim povodom nadzora nad postojećim upravnopravnim odnosom, taj odnos ukine. Pretpostavke za donošenje upravnog akta kojim se ukida posebna uporaba neovisne su o onih temeljem kojih je donesen upravni akt kojim je taj upravnopravni

50 Vidi Ivančević, V., op. cit., str. 241.

51 Ibid., str. 237.

52 Ibid., str. 245. do 246.

53 Ibid., str. 247.

54 Vidi Borković, I., op. cit., str. 360. do 362. 
odnos osnovan. ${ }^{55}$ Motivacija za ukidanje prava na posebnu uporabu obično se nalazi u naknadno nastalom sukobu interesa osobe javnoga prava i ovlaštenika posebne uporabe, koji je posljedica određenih faktičnih promjena vezanih uz zaštitu javnoga dobra, odnosno interes društvene zajednice. Radi nužnosti podizanja razine zaštite javnoga dobra ili promjene mehanizama kojima se ona provodi, legitimno stečena prava i pravni interesi ovlaštenika posebne uporabe bivaju ukinuti. ${ }^{56}$ Valja također istaknuti kako navedeno vrijedi ne samo za pitanje ukidanja posebne uporabe, nego i za postavljanje novih uvjeta u tom upravnopravnom odnosu. Posljedično napretku znanosti, tehnologija koja služi iskorištavanju javnoga dobra mijenja se, a uvjeti postavljeni upravnim aktom kojim je dopuštena posebna uporaba postaju zastarjeli i treba ih zamijeniti novima. Novi uvjeti ne postavljaju se izravno u odnosu na upravni akt koji je pravni naslov posebne uporabe, nego temeljem nadzora kojeg osoba javnoga prava obavlja radi zaštite javnoga interesa i očuvanja javnoga dobra. ${ }^{57}$

Zbog svega navedenoga, upravni akt temeljni je institut kojim se raspolaže javnim dobrom u općoj uporabi u poredbenom pravu. ${ }^{58} \mathrm{U}$ hrvatskom je pravu, međutim, upravni akt kao forma dozvole za posebnu uporabu podzastupljen. Taj javnopravni institut nešto širu primjenu ima u raspolaganju javnim vodnim dobrom. Zakonom o vodama tako je primjerice propisano da pravne i fizičke osobe mogu na dijelu javnoga vodnog dobra ostvariti prava najma, zakupa, služnosti i građenja radi ostvarenja svojih gospodarskih, odnosno osobnih potreba, a da odluku o dodjeli tih prava donose Hrvatske vode $\mathrm{u}$ upravnom postupku. ${ }^{59}$ Odluka o dodjeli prava na posebnu uporabu ovog javnog dobra stoga je upravni akt, temeljem kojega se onda sklapa jedan od taksativno navedenih ugovora građanskoga prava. Osim toga, posebna uporaba javnoga vodnog dobra u određenim slučajevima može se osnovati i vodopravnim uvjetima te vodopravnom dozvolom. Sukladno izričitim odredbama Zakona o vodama vodopravni uvjeti i vodopravna dozvola upravni su akti. ${ }^{60} \mathrm{~S}$ druge strane, posebna uporaba cesta i željezničke infrastrukture uglavnom se temelji na privatnopravnim institutima. Smatramo kako bi de lege ferenda polje primjene upravnog akata u hrvatskom zakonodavstvu valjalo proširiti. Zbog obilježja poput jednostranosti i autoritativnosti, taj javnopravni instrument omogućuje osobi javnoga prava da zainteresiranom subjektu dopusti iskorištavanje dijela javnoga dobra radi obavljanja ugostiteljske, trgovačke, gospodarske ili kakve druge djelatnosti, a da pritom zadrži nadređen pravni položaj koji će joj omogućiti da okonča upravnopravni odnos posebne uporabe kada to ocijeni neophodnim s aspekta zaštite javnoga interesa. S druge strane, zahtijeva li posebna uporaba veće investicije, duže vremensko razdoblje iskorištavanja javnoga dobra te sigurniji pravni položaj ovlaštenika, preporučljivo je za pravni naslov koristiti koncesiju.

55 Vidi Krbek, Ivo, Pravo jugoslavenske javne uprave, 3. knjiga: funkcioniranje i upravni spor, Zagreb, Birozavod, 1962., str. 43. do 44.

56 Vidi Ivančević, V., op. cit., str. 287.

57 Vidi Krbek, I., Pravo jugoslavenske ..., cit., str. 43. do 44.

58 Vidi Wolff, H., Bachof, O., Stober, R., op. cit., str. 735. do 736., Antoniolli, W., Koja, F., op. cit., str. 706. do 707., Gillet-Lorenzi, E., Traoré, S., op. cit., str. 98. do 100. i Scoca, Franco Getano, Diritto amministrativo, Torino, G. Giappichelli Editore, 2014., str. 515.

59 Članak 16. Zakona o vodama.

60 Članak 141. Zakona o vodama. 


\subsection{Koncesija}

Kako nesiguran pravni položaj ovlaštenika ne bi bio prepreka određenim oblicima posebne uporabe koji su od javnoga interesa, a zahtijevaju veća financijska ulaganja te je potrebno duže vremensko razdoblje da ovlaštenik povrati uložena sredstva, javnim dobrom može se raspolagati dodjelom koncesije. Posebna uporaba utemeljena na koncesiji podrazumijeva upravnopravni odnos nastao ustupanjem od strane osobe javnoga prava pod uvjetima i na način propisan zakonom u određenom vremenskom razdoblju prava iskorištavanja javnoga dobra, odnosno prava obavljanja određene djelatnosti na javnome dobru, često popraćenog izgradnjom i korištenjem objekata potrebnih za obavljanje te djelatnosti, fizičkoj ili pravnoj osobi na njezin trošak i rizik. ${ }^{61}$ Riječ je primarno o koncesiji dobara, koja obuhvaća pravo iskorištavanja određenoga javnog dobra. Ako se koncesijom koja je pravni naslov posebne uporabe osim prava na iskorištavanje javnoga dobra dodjeljuje i pravo pružanja javnih usluga, koncesija dobara kombinira se s koncesijom usluga. ${ }^{62}$ Za razliku od upravnog akta, ugovor o koncesiji ima obilježja dvostranog pravnog akta pa se pri njegovu sklapanju, osim volje osobe javnoga prava, u obzir uzima i volja ovlaštenika posebne uporabe. Pritom valja imati na umu kako u poredbenom pravu pravna priroda koncesije nije jednostavno pitanje. ${ }^{63}$ Neki teoretičari na koncesiju gledaju kao na jednostrani akt javne vlasti, dok prema drugima koncesija predstavlja ugovorni odnos. Đerđa smatra kako bi pravnu prirodu koncesije trebalo tumačiti s obzirom na sukob interesa koji se javlja između osobe javnoga prava koja u ulozi koncedenta nastoji u koncesijskom odnosu nastupati s aspekta iure imperii i ovisno o potrebama javnog interesa mijenjati odredbe ugovora te osobe privatnoga prava čiji je interes kao koncesionara da koncedent prema njemu nastupa što je više moguće kao ravnopravni subjekt, dakle s aspekta iure gestionis. ${ }^{64}$ Francuski teoretičari zbog toga veliki naglasak stavljaju na mješovitu pravnu prirodu ugovora o koncesiji. Jedan dio odredbi ovog ugovora naziva se naredbenim klauzulama. Naredbene klauzule koncedent može jednostrano izmijeniti u bilo kojem trenutku ako to smatra opravdanim s aspekta zaštite javnog interesa. Drugi dio odredbi ugovora o koncesiji naziva se ugovornim klauzulama. Ugovorne klauzule unesene su u ugovor kao rezultat sporazuma postignutog između koncesionara i koncedenta. Koncedent nema ovlasti jednostrano izmijeniti ugovorne klauzule. ${ }^{65}$ Zbog navedene dihotomije ugovornih odredbi, koncesija omogućava ovlašteniku posebne uporabe da u određenoj mjeri utječe na sadržaj vlastitih prava i obveza, a čak se i stipulacije oko uvjeta oduzimanja ili prestanka same koncesije nerijetko dodatno uređuju u vidu ugovornih klauzula. ${ }^{66} \mathrm{~S}$ druge strane, pravni režim ugovora o koncesiji reguliran je javnopravnim normama, stoga izvršavanje ovog ugovora bitno odstupa od ugovora građanskog prava. Odnos između osobe javnoga prava kao koncedenta te ovlaštenika posebne uporabe kao koncesionara u svojoj

61 Vidi Đerđa, D., op. cit., str. 30.

62 Ibid., str. 64.

63 Ibid., str. 101.

64 Ibid., str. 102. do 109.

65 Ibid., str. 106.

66 Vidi Omejec, J., op. cit., str. 175. 
biti je odnos subjekata upravnoga ugovora, zbog čega se ugovorne stranke nalaze u nejednakim položajima. Osoba javnoga prava nastupa s jačom voljom, jer se nalazi u ulozi zaštitnika javnog interesa, dok je ovlaštenik posebne uporabe u podređenom položaju. Posljedično tomu, koncedentu na raspolaganju stoje različita pravna sredstva kojima koncesionara može prisiliti na izvršenje njegovih obveza ako to ocjeni potrebnim. Osim toga, koncedent jedini ima ovlast jednostrano raskinuti ugovor o koncesiji ako je to nužno radi zaštite javnog interesa. Učinci jednostranog raskida ugovora o koncesiji nastupaju odmah, a dotadašnji koncesionar može svoja prava naknadno štititi pred sudom. S druge strane, relevantno zakonodavstvo koncedentu najčešće ipak ne daje pretjeranu slobodu kada je u pitanju ocjena okolnosti zbog kojih bi koncesionaru oduzeo pravo na posebnu uporabu. Zbog svega navedenog, primjena ovog javnopravnog instituta omogućuje široko ostvarivanje načela razmjernosti $u$ zaštiti javnog i privatnog interesa, pa se koncesija čini najpogodnijim sredstvom za zasnivanje posebne uporabe na duži rok.

U poredbenom je pravu dodjela koncesije uglavnom predviđena za slučajeve značajnijeg i trajnijeg raspolaganja javnim dobrom, posebice ako je u pitanju obavljanje kakve gospodarske djelatnosti. ${ }^{67}$ Navedeno pravilo u francuskom i njemačkom pravu upotpunjeno je dodatnim kriterijima razlikovanja. U Francuskoj tako koncesionar ima sigurniji pravni položaj od drugih ovlaštenika posebne uporabe. To prvenstveno dolazi do izražaja u odnosu spram koncedenta, ali i u odnosu spram trećih osoba. Naime, opozivost svih oblika ovlaštenja za posebnu uporabu jedno je od temeljnih obilježja francuskog prava javnih dobara, pa se ovlaštenici u većini slučajeva nalaze u izrazito nesigurnom pravnom položaju. Pravni položaj koncesionara ipak karakterizira nešto viši stupanj pravne sigurnosti, jer je mogućnost jednostrane izmjene ili raskida ugovora o koncesiji određena restriktivno te se pritom dosta pozornosti posvećuje financijskoj održivosti koncesionarovog poslovanja. ${ }^{68}$ Razlika između koncesije i upravnog akta

67 Vidi primjerice članak L2122-6 francuskog Općeg zakona o vlasništvu osoba javnog prava, članak 21. talijanskog Kraljevskog dekreta br. 1775 iz 1933. godine s izmjenama i dopunama iz 1994. i 2006. godine (tal. Regio decreto $n$. 1775, 1933, gia' modificato dalla legge 5 gennaio 1994, n. 36, come ulteriormente modificato dall' decreto legislativo n. 152 del 2006.), Gazzetta Ufficiale, n. 5/34., članak 14. stavak 2. njemačkog Zakona o vodnim resursima (njem. Wasserhaushaltsgesetz), Bundesgesetzblatt, I S. 2585 iz 2009., zadnja izmjena I S. 1764 iz 2016. i članak 9. austrijskog Zakona o vodama (njem. Wasserrechtgesetz), Bundesgesetzblatt I, Nr. 215/59., zadnja izmjena 54/14.

68 Vidi Gillet-Lorenzi, E., Traoré, S., op. cit., str. 108. do 110. U tom smislu Aviani i Đerđa navode kako jednostrana izmjena ugovornih odredbi od strane koncedenta često za posljedicu ima uvećanje troškova poslovanja druge ugovorne strane. Stoga se u francuskom pravu koncesionaru pruža mogućnost da se zaštiti od takvih jednostranih izmjena ugovornih odredbi pozivajući se na pravo očuvanja financijske ravnoteže ugovora. Slijedom toga, ako se naknadnom izmjenom ugovorne odredbe naruši financijska ravnoteža ugovora, koncesionar će biti ovlašten potraživati naknadu od osobe javnog prava, kako bi se na taj način financijska ravnoteža ugovora ponovno uspostavila. Ako koncesionar i koncedent ne odrede sporazumno iznos naknade, koncesionar može svoje pravo pokušati ostvariti u upravnom sporu. Osim očuvanja financijske ravnoteže ugovora, valja istaknuti još dvije teorije koje predstavljaju veliki doseg francuskog prava u ovom području, fait du prince te imprevision. Teorija fait du prince odnosi se na slučajeve u kojima je financijska ravnoteža ugovora narušena poduzimanjem određene radnje od osobe javnog prava, koja nije povezana s odredbama konkretnog ugovora, ali ima pravni učinak 
kao pravnih naslova posebne uporabe slično je koncipirana u njemačkom pravu. Posebna uporaba temeljem koncesije od posebne uporabe temeljem upravnog akta i u Njemačkoj se, osim po predmetu i opsegu mogućih korištenja javnoga dobra, razlikuje po pravnom položaju ovlaštenika. Pravni položaj koncesionara jače je zaštićen u odnosu na pravni položaj ostalih ovlaštenika posebne uporabe kojima dozvola može biti oduzeta u bilo koje doba.$^{69}$ Razlozi za jednostrani raskid ugovora o koncesiji od strane koncedenta prilično su restriktivno propisani. Osim u odnosu spram koncedenta, koncesionar je, za razliku od ostalih ovlaštenika, zaštićen i od trećih osoba. ${ }^{70}$

$\mathrm{U}$ hrvatskom zakonodavstvu koncesija nije adekvatno vrednovana $u$ raspolaganju javnim dobrom. Širu primjenu taj javnopravni institut ima samo u režimu javnoga vodnog dobra. Za svako korištenje javnog vodnog dobra koje prelazi opseg opće uporabe, odnosno slobodnog korištenja voda, sukladno Zakonu o vodama, potrebno je ishoditi koncesiju ili vodopravnu dozvola. ${ }^{71}$ Gospodarsko korištenje javnoga vodnog dobra uglavnom se temelji na koncesiji. Koncesija se tako zahtijeva za korištenje vodne snage radi proizvodnje električne energije, korištenje vodne snage za pogon uređaja, zahvaćanje voda radi korištenja za tehnološke i slične potrebe u količini većoj od 10.000,00 metara kubičnih godišnje, zahvaćanje mineralnih, termalnih i termomineralnih voda, zahvaćanje voda za navodnjavanje, zahvaćanje voda namijenjenih za ljudsku potrošnju te eksploataciju pijeska i šljunka iz obnovljivih ležišta u području značajnom za vodni režim. Koncesija može biti dodijeljena za javne usluge te javne radove, osim djelatnosti javne vodoopskrbe i javne odvodnje. Osoba koja želi obavljati gospodarsku djelatnost splavarenja, raftinga, vožnje kanuima i drugim sličnim plovilima ili pak koristiti javno vodno dobro za postavljanje plutajućih ili plovećih objekata unutar nacionalnog parka ili parka prirode, mora ishoditi koncesijsko odobrenje koje se izdaje sukladno propisima o zaštiti prirode.$^{72}$ Institutu koncesije nije, međutim, dano dovoljno prostora u režimu

na izvršavanje prava i obveza koncesionara. Slijedom navedenoga, koncesionar koji se zbog donošenja kakvog općeg akta od osobe javnog prava našao u nepovoljnijem položaju od onoga u kojem je bio kada je sklopio ugovor o koncesiji, ovlašten je od osobe javnog prava potraživati naknadu pretrpljene štete ili odobrenje za povećanje naknade koju ubire od korisnika javnog dobra. Teorija imprevision odnosi se na slučajeve u kojima su se, nakon sklapanja upravnog ugovora, okolnosti koje su postojale kada je ugovor bio sklopljen toliko promijenile, da je izvršenje ugovora za neku od ugovornih stranaka postalo neekonomično. Okolnosti zbog kojih je ugovornoj stranci postalo neekonomično izvršavati ugovor o koncesiji morale su nastupiti nakon sklapanja samog ugovora, ne smiju biti povezane s radom javne vlasti i moraju biti izvanrednog karaktera. Ako u ugovoru nema odredbi koje uređuju postupanje u takvim okolnostima, koncesionar može tražiti njegov raskid. Međutim, u tom slučaju osoba javnog prava može odbiti raskinuti ugovor te prisiliti koncesionara da nastavi izvršavati svoje ugovorne obveze. Koncesionar je tada ovlašten potraživati naknadu svih nepredviđenih troškova, koje mu osoba javnog prava treba isplatiti. Aviani, Damir, Đerđa, Dario, Aktualna pitanja pravnog uređenja upravnih ugovora u hrvatskom pravu, Zbornik radova Pravnog fakulteta Sveučilišta u Splitu, vol. 48, br. 3(2011), str. 483. do 484.

69 Vidi Papier, H., op. cit., str. 126.

70 Vidi Omejec, J., op. cit., str. 178.

71 Članak 79. Zakona o vodama.

72 Članci 158., 163. i 171. Zakona o vodama. 
ostalih javnih dobara. Koncesija kao pravni osnov posebne uporabe propisana je samo još u slučaju korištenja cesta. Zakonom o cestama tako je omogućena dodjela koncesije za korištenje cestovnog zemljišta radi izgradnje pratećih uslužnih objekata i obavljanja djelatnosti ugostiteljstva, trgovine, usluga opskrbe gorivom, servisnih usluga i sl. ${ }^{73}$

Smatramo kako bi de lege ferenda primjenu koncesije valjalo proširiti na slučajeve osnivanja posebne uporabe u kojima upravni akt sam po sebi ne predstavlja primjeren pravni naslov. U okolnostima kada je raspolaganje javnim dobrom od strateškog, odnosno gospodarskog interesa za osobu javnoga prava, upravni akt kao javnopravni instrument koji javnoj vlasti omogućuje iznimno široku dispoziciju preinake i ukidanja upravnopravnog odnosa, prejako izražava autoritet vlasti. S druge strane, građanskopravni ugovor bi osobi javnoga prava onemogućio jednostran i autoritativni zahvat u nastali građanskopravni odnos, pa bi ovlaštenik posebne uporabe, pozivajući se na slobodu ugovaranja i ravnopravnost ugovornih stranaka, potencijalno mogao ugroziti javni interes. U takvim slučajevima koncesija predstavlja svojevrstan kompromis, koji nadilazi neadekvatnost upravnog akta i ugovora građanskog prava te omogućuje ostvarivanje željene javne svrhe. ${ }^{74}$

\subsection{Ugovor}

Njemački pravni sustav dopušta raspolaganje javnim dobrom u općoj uporabi ugovorima građanskoga prava. Pritom nisu propisana ograničenja u pogledu vrste pravnog posla. No, za sve takve pravne poslove vrijedi zajedničko pravilo: privatnopravno raspolaganje nije dopušteno ako bi utjecalo na opću uporabu javnoga dobra. ${ }^{75}$ Svrha javnoga dobra ne smije biti ugrožena pravnim poslovima privatnoga prava. Posljedično tomu, u praksi nema puno primjera raspolaganja javnim dobrom ugovorima građanskoga prava, s obzirom na to da većina pojavnih oblika posebne uporabena nekinačin ograničavaili isključuje opću uporabu. ${ }^{76}$ Za razliku od njemačkoga prava, u hrvatskom pravu raspolaganje javnim dobrom ugovorima građanskog prava široko je omogućeno te pritom nisu uvijek implementirani adekvatni mehanizmi zaštite javnoga interesa. Štoviše, posebna uporaba cesta i željezničke infrastrukture osniva se uglavnom građanskopravnim ugovorima. Zakonom o cestama propisano je da se na cesti može osnovati pravo služnosti i pravo građenja radi izgradnje komunalnih, vodnih, energetskih građevina i građevina elektroničkih komunikacija i povezane opreme. Osim toga dio ceste može se dati na korištenje radi obavljanja pratećih djelatnosti ugovorom o korištenju cestovnog zemljišta na koji se primjenjuju odredbe ugovora o zakupu. ${ }^{77}$ Dodatno je propisano kako se dio nerazvrstane ceste namijenjen pješacima može dati u zakup. ${ }^{78}$ Subjekt javnoga prava koji upravlja cestom ovlašten je sklapati

73 Članak 75. stavak 1. Zakona o cestama.

74 Vidi Ivančević, V., op. cit., str. 242.

75 Vidi Papier, H., op. cit., str. 112., Wolff, H., Bachof, O., Stober, R., op. cit., str. 736. do 737. i

Antoniolli, W., Koja, F., op. cit., str. 706.

76 Vidi Wolff, H., Bachof, O., Stober, R., op. cit., str. 738. do 739.

77 Članak 3. Zakona o cestama.

78 Članak 101. stavak 3. Zakona o cestama. 
navedene ugovore bez obzira na to ograničava li se, odnosno isključuje li se pritom opća uporaba javnoga dobra. Kao što je ranije napomenuto, hrvatsko zakonodavstvo nije prepoznalo i primjereno vrednovalo institut javne namjene javnoga dobra. Stoga se niti opća uporaba ne prepoznaje kao apsolutni imperativ javnoga interesa kojemu bi trebalo pružiti zaštitu u slučaju ugroze. Taj temeljni nedostatak pravnih propisa rezultirao je time da se u hrvatskome pravu, protivno svim osnovnim postulatima prava javnih dobara, ugovorima građanskoga prava može dopustiti posebna uporaba ceste koja potencijalno ograničava ili isključuje opću uporabu. Predmetno zakonsko rješenje nije najbolje jer omogućava osobi javnoga prava raspolaganje javnim dobrom na način koji je možebitno protivan javnome interesu. Raspolaganje željezničkom infrastrukturom nešto je bolje uređeno. Zakonom o željeznici propisano je kako upravitelj infrastrukture može osnovati pravo služnosti, odnosno pravo građenja za potrebe građenja ili unaprjeđenja drugog infrastrukturnog sustava na dijelu željezničke infrastrukture, ali samo pod uvjetom da se time ne gubi funkcionalnost željezničke infrastrukture. ${ }^{79}$ Smatramo da iz navedene odredbe proizlazi kako se željezničkom infrastrukturom ne smije raspolagati sklapanjem ugovora o osnivanju dvaju navedenih ograničenih stvarnih prava, ako bi time bio ograničen ili isključen željeznički promet kao osnovni oblik opće uporabe toga javnog dobra.

Dodatni problem predstavlja okolnost kako se u podlozi raspolaganja cestama i željezničkom infrastrukturom ne nalazi niti jedan javnopravni institut. Odredbe Zakona o cestama i Zakona o željeznici ne uređuju postupak dodjele prava na posebnu uporabu, što je već samo po sebi loše pravno rješenje. Kada su u pitanju ceste ovaj postupak je uređen Pravilnikom o korištenju cestovnog zemljišta i obavljanju pratećih djelatnosti na javnoj cesti, kojim je propisano kako se korištenje cestovnog zemljišta povjerava korisnicima javnim nadmetanjem, a u određenim slučajevima i izravnom pogodbom. ${ }^{80}$ Pritom nije određena pravna priroda odluke o dodjeli prava na posebnu uporabu. Kada je u pitanju željeznička infrastruktura, postupak raspolaganja nije uređen ni Zakonom o željeznici, niti podzakonskim općim aktima koji bi bili doneseni za izvršenje toga Zakona. S obziromna to da se željeznička infrastruktura nalazi u državnome vlasništvu, na postupak raspolaganja tim dobrom primjenjuju se propisi o raspolaganju državnom imovinom, ponajprije Zakon o upravljanju i raspolaganju imovinom u vlasništvu Republike Hrvatske. ${ }^{81}$ Potonjim Zakonom određeno je kako se raspolaganje nekretninama, provodi javnim nadmetanjem, javnim prikupljanjem ponuda ili kombinacijom tih dvaju postupaka. ${ }^{82}$ Iznimno, imovinom se može raspolagati i bez provedbe javnog nadmetanja, odnosno javnog prikupljanja ponuda, ali samo u zakonom propisanim slučajevima. ${ }^{83}$ Zakonom o upravljanju i raspolaganju imovinom u vlasništvu Republike Hrvatske, kao i podzakonskim općim aktima

79 Članak 13. stavak 4. Zakona o željeznici.

80 Članak 11. stavak 1. Pravilnika o korištenju cestovnog zemljišta i obavljanju pratećih djelatnosti na javnoj cesti, Narodne novine, br. 78/14.

81 Članak 4. stavak 1. točka 7. Zakona o upravljanju i raspolaganju imovinom u vlasništvu Republike Hrvatske.

82 Članak 51. stavak 1. Zakona o upravljanju i raspolaganju imovinom u vlasništvu Republike Hrvatske.

83 Članak 52. Zakona o upravljanju i raspolaganju imovinom u vlasništvu Republike Hrvatske. 
donesenima za njegovo izvršenje, također nije propisana pravna priroda odluke o dodjeli prava na posebnu uporabu. Čini se kako je, de lege lata, odluka o kojim se osniva posebna uporaba ceste, odnosno željezničke infrastrukture po pravnoj prirodi akt poslovanja. Akt poslovanja donosi osoba javnoga prava kada odlučuje o raspolaganju prirodnim bogatstvom te drugim dobrom kao nositelj vlasničkih prava ${ }^{84}$ Riječ je neupravnom aktu koji proizlazi iz vlasničkopravne ovlasti na nekom dobru. Bitno je obilježje akta poslovanja da on nije rezultat provedenoga upravnog postupka, niti se njime rješava o upravnoj stvari. Kako akt poslovanja nije upravni akt, tako se i njegova zakonitost ne može osporavati u upravnom sporu. ${ }^{85}$ Đerđa ističe kako se zaštita i unaprjeđenje gospodarskih i drugih državnih interesa najučinkovitije postiže upravo primjenom javnopravnih instrumenata, pa nije jasno zašto je zakonodavac oslabio javnopravnu komponentu ovlasti države da autoritativnim mjerama štiti dobra u svojemu vlasništvu. ${ }^{86}$ Postojeće pravno rješenje nije svrhovito s gledišta zaštite javnoga interesa, stoga smatramo da bi odluku o odabiru najpovoljnijeg ponuditelja de lege ferenda trebalo odrediti kao upravni akt. Za takvo pravno uređenje već postoji i solidna teorijska podloga ${ }^{87}$ Prema Krbeku, upravni akt i građanskopravni ugovor mogu djelovati na isti predmet. Upravni akt može imati građanskopravne posljedice ako ovlašćuje svoga adresata da zaključi građanskopravni ugovor. Upravni akt javlja se kao pretpostavka za sklapanje građanskopravnog posla. U tim slučajevima do građanskopravnog djelovanja dolazi samo pod pretpostavkom i u granicama kako je utvrđeno upravnim aktom. Pritom valja istaknuti, kako se zbog navedenog građanskopravnog djelovanja upravni akt ne pretvara u građanskopravni posao, nego predstavlja preduvjet nastanka, djelovanja i prestanka građanskopravnog odnosa. ${ }^{88}$ Polaganje cijevi ili kablova u zemljišno tijelo javnoga dobra tako bi se moglo regulirati ugovorom o služnosti sklopljenim s ovlaštenikom posebne uporabe koji bi svoje pravo korištenja javnoga dobra izvodio iz upravnog akta ili koncesije. Pravo izgradnje određenih građevina na javnom dobru koje ne prate vlasničkopravni status toga dobra moglo bi se regulirati kao pravo građenja čiji je nositelj ovlaštenik posebne uporabe koji bi svoje pravo korištenja javnoga dobra izvodio iz koncesije. Objekti ograničenih stvarnih prava mogli bi se koristiti isključivo radi obavljanja djelatnosti posebne uporabe i pod uvjetima određenima dozvolom za posebnu uporabu.

84 Vidi Stipić, Milan, Koncesije u hrvatskom zakonodavstvu i praksi (opća razmatranja i neki primjeri), Aktualna pitanja hrvatskog gospodarstva i pravne prakse: zbornik radova, Zagreb, 1996., str. 64.

85 Vidi Đerđa, Dario, Dvojbe o pravnoj prirodi odluke o davanju na korištenje poljoprivrednog zemljišta, šume ili šumskog zemljišta u državnom vlasništvu, Novosti u upravnom pravu i upravnosudskoj praksi: zbornik radova, Zagreb, Organizator, 2016., str. 149. i Ljubanović, Boris, Pojmovnik, Hrvatska javna uprava, vol. 9., br. 4(2009), str. 1249.

86 Đerđa, D., Dvojbe ..., cit., str. 143.

87 Osim toga, koncept sukladno kojemu bi javnopravni instrument bio temelj za sklapanje ugovora građanskoga prava kojim se regulira pravo posebne uporabe već je prepoznat i u zakonodavstvu, jer Zakon o vodama kao preduvjet sklapanja ugovora građanskog prava zahtijeva prethodnu provedbu upravnog postupka i donošenje upravnog akta.

88 Vidi Krbek, I., Pravo jugoslavenske ..., cit., str. 7. 


\section{ZAKLJUČAK}

Temeljni kriterij dodjele statusa javnoga dobra u općoj uporabi nekom dijelu materijalnoga svijeta njegova je opća društvena funkcija. Javnome interesu kojega društvena zajednica ima spram javnoga dobra pruža se visok stupanj zaštite. Ta zaštita implicira bitna ograničenja vlasničkih ovlasti koje osoba javnoga prava obavlja na javnome dobru, a koja su najvidljivija u kontekstu raspolaganja tim dobrom. U poredbenom pravu osoba javnoga prava tako nije ovlaštena otuđiti javno dobro, niti je ovlaštena privatnopravnim poslovima ograničiti, odnosno isključiti opću uporabu toga dobra. Posljedično tomu, pravni status javnoga dobra u općoj uporabi gotovo je jednak onomu res extra commercium. Svrha propisivanja tako strogih ograničenja vlasničkih ovlasti ista je u svim državama, a očituje se u nužnosti zaštite javnoga interesa. U Republici Hrvatskoj zabrana otuđenja nije izričito propisana u pogledu svih javnih dobara, a pojedinim dobrima može se raspolagati ugovorima privatnoga prava bez obzira na utjecaj koje to raspolaganje ima na opću uporabu. Pravni režim dopuštenih oblika raspolaganja javnim dobrom neprecizan je i opterećen mnogim nedostatcima. Analiziramo li pravni okvir raspolaganja trima kategorijama javnih dobara kao cjelinu, razvidna je njegova nekoherentnost, neujednačenost i nedosljednost. Pod pritiskom privatnih interesa, javni interes stoga potencijalno može biti ugrožen i potisnut u drugi plan.

Radi osiguravanja primjerene razine zaštite javnoga interesa, valjalo bi ujednačiti i unaprijediti režim raspolaganja javnim vodnim dobrom, cestama i željezničkom infrastrukturom. Zabrana otuđenja javnoga dobra u općoj uporabi propisana je Zakonom o vodama i Zakonom o cestama. Istovjetnu zabranu valjalo bi de lege ferenda propisati i Zakonom o željeznici. Zabrana stjecanja vlasništva dosjelošću propisana je samo u odnosu na javno vodno dobro, pa bi ju trebalo normirati i u pogledu cesta te željezničke infrastrukture. Povrh toga, prijeko potrebnim smatramo nedvosmisleno izuzimanje javnoga dobra od ovrhe te propisivanje zabrane opterećenja javnoga dobra stvarnopravnim osiguranjem tražbine. Iako je Zakonom o vodama određena zabrana opterećenja javnoga vodnog dobra založnim pravom, to pravno rješenje samo po sebi nije dovoljno. Javno dobro i dalje, teoretski, može biti predmetom ovrhe i nad njime bi se pravo vlasništva moglo steći ovršnom prodajom. Mogućnost prisilnoga namirenja tražbine na javnome dobru u općoj uporabi iz tog razloga treba isključiti izričitom zakonskom normom. Također bi trebalo zasebno normirati slučajeve raspolaganja javnim dobrom koji za rezultat imaju ograničenje, odnosno isključenje opće uporabe. Pravni naslov posebne uporabe poglavito bi trebao biti upravni akt. Brojni su razlozi koji govore tomu u prilog. Upravni akt omogućuje osobi javnoga prava presudan utjecaj na osnivanje upravnopravnog odnosa posebne uporabe u kojemu će se ovlaštenik nalaziti u podređenom položaju. Jednako je važna i ovlast osobe javnoga prava da utječe na već osnovan odnos posebne uporabe. Zahvaljujući toj ovlasti, ona može ovlašteniku posebne uporabe naknadno postavljati nove uvjete i nametati mu nove obveze radi boljeg gospodarenja javnim dobrom ili ostvarivanja interesa društvene zajednice. Konačno, nastane li između osobe javnoga prava i ovlaštenika posebne uporabe sukob interesa koji je posljedica određenih faktičnih promjena vezanih uz 
zaštitu javnoga dobra, odnosno interes društvene zajednice ili pak ovlaštenik posebne uporabe prestane izvršavati svoje obveze, osoba javnoga prava opozvati će dozvolu za posebnu uporabu. Iz navedenoga je razvidno da upravni akt omogućuje osobi javnoga prava primjenu različitih mehanizama usmjerenih zaštiti javnog interesa u svim fazama posebne uporabe. Posljedično tomu, pravni položaj ovlaštenika posebne uporabe ovisi o razini zaštite koju u danom trenutku valja pružiti javnome interesu. Zahtijeva li posebna uporaba veće investicije, duže vremensko razdoblje iskorištavanja javnoga dobra te sigurniji pravni položaj ovlaštenika, preporučljivo je za njezin pravni naslov koristiti koncesiju. Za razliku od upravnog akta, koncesija omogućuje ovlašteniku posebne uporabe određeni utjecaj na sadržaj vlastitih prava i obveza te mu daje šire ovlasti spram osobe javnoga prava i trećih osoba. S druge strane, pravila o sklapanju, izvršenju i raskidu ugovora o koncesiji javnopravne su naravi. Volja osobe javnoga prava od presudnog je utjecaja na nastanak prava i obveza u koncesijskom odnosu. Osim toga, osoba javnoga prava kao koncedent na raspolaganju ima i pravna sredstva kojima može utjecati na sadržaj koncesijskog odnosa. Konačno, osoba javnoga prava ovlaštena je jednostrano raskinuti ugovor o koncesiji kada to ocijeni nužnim $\mathrm{s}$ aspekta zaštite javnoga interesa. Zbog svega navedenoga, koncesiju bi kao pravni naslov posebne uporabe valjalo koristiti u slučajevima posebne uporabe od većega gospodarskog značaja, u sklopu koje ovlaštenik ima ulogu strateškog partnera osobe javnoga prava u ostvarivanju cilja od širega društvenog interesa.

Ugovor građanskoga prava ne smatramo primjerenim instrumentom za raspolaganje javnim dobrom u slučaju kada posebna uporaba ograničava, odnosno isključuje opću uporabu. Građanskopravne ugovore karakterizira sloboda ugovaranja i ravnopravnost ugovornih stranaka. Osoba javnoga prava stoga ne odlučuje jednostrano o raspolaganju javnim dobrom, nego mora postići suglasnost volja $\mathrm{s}$ potencijalnim ovlaštenikom posebne uporabe. Jednom osnovani građanskopravni odnos posebne uporabe načelno se temelji na koordinaciji stranaka, pa osoba javnoga prava u tom odnosu ne sudjeluje kao nositelj autoriteta vlasti. Posljedično navedenome, osoba javnoga prava nema jednu od ključnih ovlasti nužnih za zaštitu javnoga interesa vezanog uz javno dobro, a to je ovlast jednostrane modifikacije nastalog odnosa posebne uporabe. Povrh toga, ako ovlaštenik ne izvršava svoje obveze iz posebne uporabe ili na drugi način ugrožava javni interes, osoba javnoga prava nije ovlaštena jednostranim i autoritativnim aktom okončati posebnu uporabu. Zaštitu javnoga interesa osoba javnoga prava mora zahtijevati pred redovitim sudom u građanskoj parnici, gdje mogućnost pružanja trenutačne zaštite javnome dobru ovisi o eventualnom izricanju privremenih mjera. S obzirom na sve navedeno, smatramo da bi de lege ferenda primjenu građanskopravnih ugovora trebalo ograničiti na slučajeve raspolaganja javnim dobrom koje ne utječe na opću uporabu. Sveobuhvatnom analizom ovoga pravnog pitanja valjalo bi iznaći model u sklopu kojega bi se sklapanje ugovora građanskog prava vezalo uz prethodnu dodjelu prava na posebnu uporabu upravnim aktom ili koncesijom, jer bi radi zaštite javnoga interesa javnopravni institut svakako morao biti u podlozi svakog raspolaganja javnim dobrom. Konačno, stajališta smo kako bi važnom i kompleksnom pravnom pitanju kao što je zaštita javnoga interesa u raspolaganju javnim dobrom u općoj uporabi u daljnjim istraživanjima trebalo 
posvetiti više pozornosti. Uvažavajući poredbeno-pravna iskustva, hrvatsko pravo moralo bi pronaći vlastiti pristup navedenoj problematici koji bi bio sukladan potrebama društvene zajednice i zahtjevima održivog razvoja javne imovine.

\section{LITERATURA}

Pravni izvori

1. Austrija, Republika, Wasserrechtgesetz, Bundesgesetzblatt I, Nr. 215/59., zadnja izmjena 54/14.

2. Francuska, Republika, Code general de la propriete des personnes publiques, službeni pročišćeni tekst dostupan na:

https://www.legifrance.gouv.fr/affichCode.do?cidTexte=LEGITEXT000006070299\&da teTexte $=20080505$ (16. 12. 2016.)

3. Hrvatska, Republika, Ustav Republike Hrvatske, Narodne novine, br. 56/90., 135/97., 8/98., 113/00., 124/00., 28/01., 41/01., 55/01., 76/10., 85/10. - pročišćeni tekst, 5/14.

4. Hrvatska, Republika, Zakon o cestama, Narodne novine, br. 84/11., 22/13., 54/13., 148/13., 92/14.

5. Hrvatska, Republika, Zakon o upravljanju i raspolaganju imovinom u vlasništvu Republike Hrvatske, Narodne novine, br. 94/13., 18/16.

6. Hrvatska, Republika, Zakon o uređivanju imovinskopravnih odnosa u svrhu izgradnje infrastrukturnih građevina, Narodne novine, br. 80/11.

7. Hrvatska, Republika, Zakon o vlasništvu i drugim stvarnim pravima, Narodne novine, br. 91/96., 68/98., 137/99., 22/00., 73/00., 129/00., 114/01., 79/06., 141/06., 146/08., 38/09., 153/09., 143/12., 152/14.

8. Hrvatska, Republika, Zakon o vodama, Narodne novine, br. 153/09., 63/11., 130/11., 56/13., 14/14.

9. Hrvatska, Republika, Zakon o željeznici, Narodne novine, br. 94/13., 148/13.

10. Hrvatska, Republika, Pravilnik o korištenju cestovnog zemljišta i obavljanju pratećih djelatnosti na javnoj cesti, Narodne novine, br. 78/14.

11. Italija, Republika, Codice civile, Gazzetta Ufficiale, n. 79/42., zadnja izmjena n. 202/16.

12. Italija, Republika, Regio decreto n. 1775, 1933, gia' modificato dalla legge 5 gennaio 1994, n. 36, come ulteriormente modificato dall' decreto legislativo n. 152 del $2006 .$, Gazzetta Ufficiale, n. 5/34.

13. Njemačka, Savezna Republika, Wasserhaushaltsgesetz, Bundesgesetzblatt, I S. 2585 iz 2009., zadnja izmjena I S. 1764 iz 2016.

14. Srbija, Republika, Zakon o javnoj svojini, Službeni glasnik Republike Srbije, br. 72/11., 88/13., 105/14.

Monografije, članci, vrela s interneta

1. Antoniolli, Walter, Koja, Friedrich, Allgemeines Verwaltungsrecht, Wien, Manzsche Verlags- und Universitätsbuchhandlung, 1996.

2. Auby, Jean-Marie, Bonn, Pierre, Droit administratif des biens, 3. izd., Paris, Dalloz, 1995.

3. Aviani, Damir, Đerđa, Dario, Aktualna pitanja pravnog uređenja upravnih ugovora u hrvatskom pravu, Zbornik radova Pravnog fakulteta Sveučilišta u Splitu, vol. 48, br. 3(2011), str. 475 do 486.

4. Borković, Ivo, Upravno pravo, 7. izd., Zagreb, Narodne novine, 2002.

5. Đerđa, Dario, Dvojbe o pravnoj prirodi odluke o davanju na korištenje poljoprivrednog zemljišta, šume ili šumskog zemljišta u državnom vlasništvu, Novosti u upravnom pravu i upravnosudskoj praksi: zbornik radova, Zagreb, Organizator, 2016. 
6. Đerđa, Dario, Upravnopravni aspekti koncesija, doktorska disertacija, Split, Pravni fakultet Sveučilišta u Splitu, 2005.

7. Gavella, Nikola ... [et al.], Stvarno pravo - posebna pravna uređenja, Zagreb, Narodne novine, 2011.

8. Gavella, Nikola ... [et al.], Stvarno pravo - svezak 1., Zagreb, Narodne novine, 2007.

9. Gillet-Lorenzi, Emmanuelle, Traoré, Seydou, Droit administratif des biens, Paris, Centre National de la Fonction Publique Territoriale, 2007.

10. Ivančević, Velimir, Institucije upravnog prava, knjiga 1., Zagreb, Pravni fakultet Sveučilišta u Zagrebu, 1983.

11. Krbek, Ivo, Pravo jugoslavenske javne uprave, 3. knjiga: funkcioniranje i upravni spor, Zagreb, Birozavod, 1962.

12. Krbek, Ivo, Upravni akt, Zagreb, Jugoslavenska akademija znanosti i umjetnosti, 1957.

13. Kromer, Michael, Sachenrecht des Offentlichen Rechts: Probleme und Grundlagen eines Allgemeinen Teils des Offentlichen Sachenrechts (Schriften zum Offentlichen Recht), Berlin, Duncker \& Humblot, 1985.

14. Ljubanović, Boris, Pojmovnik, Hrvatska javna uprava, vol. 9., br. 4(2009), str. 1249.

15. Omejec, Jasna, Površinske tekuće vode kao dobro u općoj uporabi (osnove prava javnih stvari), doktorska disertacija, Zagreb, Pravni fakultet Sveučilišta u Zagrebu, 1993.

16. Papier, Hans Jürgen, Recht der Öffentlichen Sachen, Berlin, Walter de Gruyter, 1977.

17. Popovski, Aleksandra, Upravnopravni aspekti upravljanja i korištenja javnoga dobra u općoj uporabi, doktorska disertacija, Zagreb, Pravni fakultet Sveučilišta u Zagrebu, 2016.

18. Pusić, Eugen, Društvena regulacija, Granice znanosti i iskustva, Zagreb, Pravni fakultet Sveučilišta u Zagrebu, 1989.

19. Stipić, Milan, Koncesije u hrvatskom zakonodavstvu i praksi (opća razmatranja i neki primjeri), Aktualna pitanja hrvatskog gospodarstva i pravne prakse: zbornik radova, Zagreb, 1996.

20. Virant, Gregor, Pojem in pravni režim javnega dobra, magistrsko delo, Ljubljana, Pravna falkulteta Univerza v Ljubljani, 1990.

21. Visković, Nikola, Teorija države i prava, Zagreb, Birotehnika, 2001.

22. Waline, Marcel, Droit administratif, 8. izd., Paris, Sirey, 1959.

23. Wolff, Hans J., Bachof, Otto, Stober, Rolf, Verwaltungsrecht, Band 2, München, Verlag C. H. Beck, 2000. 
Summary

\section{PROTECTION OF PUBLIC INTEREST IN DISPOSAL OF PUBLIC GOOD}

The interest of the community regarding the use of public good is legally acknowledged as a public interest. In order to protect the public interest, a person of public law is not allowed to alienate the public good, nor burden it with certain forms of security rights. The power to dispose the public good is reduced to issuing licenses for the temporary and revocable use of the good that goes beyond general use. Approval may be issued in the form of an administrative act, concession or contract. Administrative act and concession enable the application of various remedies by which person of public law may protect the public interest. On the other hand, the contract as a legal basis for the use of public good does not allow a person of public law to enforce authoritative action and immediately protect the public interest. Nevertheless, administrative act and concession are underrepresented in the Croatian legislation, while contract has been given considerable space. Therefore, the subject of the article is the analysis of the regime of disposal of the public good, in order to critically address the adequacy of Croatian positive regulation from the viewpoint of the protection of the public interest, as well as to propose regulatory intervention in order to improve the present legal framework.

Keywords: public good, property, disposition, general use, special use, administrative act, concession, contract.

Zusammenfassung

\section{SCHUTZ DES ÖFFENTLICHEN INTERESSES BEI DER ENTSORGUNG DES ÖFFENTLICHEN GUTES}

Das Interesse der Gemeinde an der Nutzung des öffentlichen Gutes ist gesetzlich als öffentliches Interesse anerkannt. Mit dem Ziel des Schutzes des öffentlichen Interesses darf eine Person des öffentlichen Rechts das öffentliche Gut weder entfremden, noch es mit bestimmten Formen von Sicherheitsrechten belasten. Die Befugnis das öffentliche Gut zu entsorgen, ist durch die Erteilung von Lizenzen für die vorübergehende und widerrufliche Nutzung des Gutes, die über den allgemeinen Gebrauch hinausgehen, eingeschränkt. Die Genehmigung kann in Form eines Verwaltungsakts, einer Konzession oder eines Vertrags erteilt werden. Der Verwaltungsakt und die Konzession ermöglichen eine Anwendung verschiedener Rechtsmittel, durch welche die Person des öffentlichen Rechts das öffentliche Interesse schützen kann. Auf der anderen Seite erlaubt der Vertrag als Rechtsgrundlage für die Nutzung öffentlicher Güter nicht, dass eine Person des öffentlichen Rechts 
eine maßgebliche Handlung durchsetzt und das öffentliche Interesse unmittelbar schützt. Nichtsdestotrotz sind der Verwaltungsakt und die Konzession in der kroatischen Gesetzgebung unterrepräsentiert, im Gegensatz zum Vertrag. Daher ist das Thema dieser Arbeit eine Analyse des Regimes der Beseitigung des öffentlichen Gutes, um die Angemessenheit der kroatischen Positivregulierung unter dem Gesichtspunkt des Schutzes des öffentlichen Interesses kritisch zu behandeln und eine Regulierungsintervention vorzuschlagen, mit dem Ziel einer Verbesserung des bestehenden Rechtsrahmens.

Schlüsselwörter: öffentliches Gut, Eigentum, Anordnung, allgemeine Verwendung, besondere Verwendung, Verwaltungsakt, Konzession, Vertrag.

Riassunto

\section{LA TUTELA DELL'INTERESSE PUBBLICO NELL'UTILIZZO DEL DEMANIO PUBBLICO}

L'interesse che la collettività ha con riguardo all'utilizzo del demanio pubblico è riconosciuto come interesse pubblico. Al fine di tutelare l'interesse pubblico, il soggetto di diritto pubblico non è autorizzato all'alienazione del demanio; né il bene può essere gravato da garanzie reali del debito. La possibilità di disporre di beni demaniali si limita al permesso di dare il bene demaniale per un periodo di tempo in concessione revocabile per usi che esulano dall'uso pubblico. L'approvazione può essere data in forma di atto amministrativo, di concessione o di contratto. L'atto amministrativo e la concessione permettono l'applicazione di diversi strumenti legali con i quali il soggetto di diritto pubblico può influire sul contenuto del rapporto giuridico amministrativo e può tutelare l'interesse pubblico nel caso in cui lo stesso sia in pericolo. Dall'altra parte, il contratto quale fondamento giuridico per l'utilizzo del bene demaniale non permette al soggetto di diritto pubblico di intervenire in maniera autoritativa, come nemmeno di garantire una tutela immediata dell'interesse pubblico. Ciononostante, nella legislazione croata l'atto amministrativo e la concessione non godono di una regolamentazione appropriata; mentre ai contratti viene dato ampio spazio. L'oggetto del presente lavoro è pertanto l'analisi del regime di disposizione dei beni demaniali al fine di interrogarsi in chiave critica sulla bontà delle leggi positive croate dal punto di vista della tutela del demanio e di proporre interventi normativi nell'intento di migliorare il quadro normativo esistente.

Parole chiave: demanio, proprietà, disponibilità, uso pubblico, uso particolare, atto amministrativo, concessone, contratto. 
